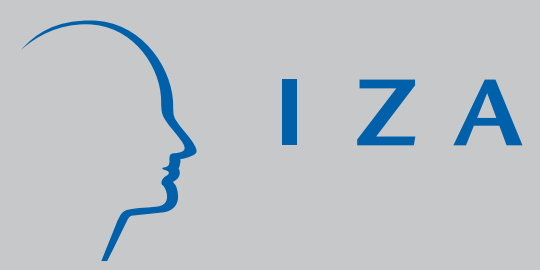

IZA DP No. 2441

The Effect of Family Structure on Parents' Child Care Time in the United States and the United Kingdom

Charlene M. Kalenkoski

David C. Ribar

Leslie S. Stratton

November 2006 


\title{
The Effect of Family Structure on Parents' Child Care Time in the United States and the United Kingdom
}

\author{
Charlene M. Kalenkoski \\ Ohio University \\ David C. Ribar \\ University of North Carolina at Greensboro \\ and IZA Bonn \\ Leslie S. Stratton \\ Virginia Commonwealth University \\ and IZA Bonn
}

Discussion Paper No. 2441

November 2006

\author{
IZA \\ P.O. Box 7240 \\ 53072 Bonn \\ Germany \\ Phone: +49-228-3894-0 \\ Fax: +49-228-3894-180 \\ E-mail: iza@iza.org
}

\begin{abstract}
Any opinions expressed here are those of the author(s) and not those of the institute. Research disseminated by IZA may include views on policy, but the institute itself takes no institutional policy positions.

The Institute for the Study of Labor (IZA) in Bonn is a local and virtual international research center and a place of communication between science, politics and business. IZA is an independent nonprofit company supported by Deutsche Post World Net. The center is associated with the University of Bonn and offers a stimulating research environment through its research networks, research support, and visitors and doctoral programs. IZA engages in (i) original and internationally competitive research in all fields of labor economics, (ii) development of policy concepts, and (iii) dissemination of research results and concepts to the interested public.
\end{abstract}

IZA Discussion Papers often represent preliminary work and are circulated to encourage discussion. Citation of such a paper should account for its provisional character. A revised version may be available directly from the author. 
IZA Discussion Paper No. 2441

November 2006

\section{ABSTRACT}

\section{The Effect of Family Structure on Parents' Child Care Time in the United States and the United Kingdom}

We use time-diary data from the 2003 and 2004 American Time Use Surveys and the 2000 United Kingdom Time Use Study to estimate the effect of family structure on the time mothers and fathers spend on primary and passive child care and on market work, using a system of correlated Tobit equations and family structure equations. Estimates from these models indicate that single parents in both countries spend more time in child care than married or cohabiting parents. There are differences, however, in market work with single parents in the U.S. working more than other parents and single parents in the U.K. working less.

JEL Classification: J1, J2

Keywords: $\quad$ time use, child care, family structure

Corresponding author:

Charlene M. Kalenkoski

Department of Economics

Ohio University

Bentley Annex 351

Athens, OH 45701

USA

E-mail: kalenkos@ohio.edu 


\section{The Effect of Family Structure on Parents' Child Care Time in the United States and the United Kingdom}

I. Introduction

Estimates of the cost of raising a child abound but are typically limited to the monetary expenditures necessary to feed, clothe, house, provide medical care to, and sometimes educate a child. However the time that parents devote to caring for their children also represents an enormous, yet sometimes underappreciated, investment in child rearing and recent trends in family structure and in women's employment may put these investments at risk. The rise in single-parent households means that fewer families can rely on the services of two adults to provide for child care. The rise in cohabitation as an alternative to marriage may have a detrimental effect given the generally weaker intrahousehold ties and the shorter duration of cohabiting relationships. In addition, women’s increasing labor force attachment and the trend towards dual career households impose further constraints that may reduce the time devoted to child care.

Parents’ provision of care is valuable as it contributes to children's safety and good health as well as to their emotional and intellectual development. The health and well-being of the parents is also affected, both by the satisfaction most parents derive from their children's wellbeing and by the stress induced by the additional time commitments. For these reasons it is important that we understand the characteristics that help and hinder caregiving.

Our focus is on examining these characteristics. To do so, we use time-diary data from the 2003 and 2004 American Time Use Surveys (ATUS) and the 2000 United Kingdom Time Use Study (UKTUS), giving particular attention to the effects of family structure on caregiving. Unlike previous economic studies, such as Kooreman \& Kapteyn (1987) and Hallberg \& 
Klevmarken (2003), which have analyzed alternative child care activities but only among twoparent families, we examine differences among married, cohabiting, and single-parent families. We also look at families of different sizes. As parents' living arrangements and the number of children are both behaviorally determined, we also account for the likely endogeneity of these characteristics by estimating a system of equations and employing factor-analytic controls for unobserved variables.

The data in the ATUS and UKTUS have several other features that strengthen our analysis. First, the relatively large size of the surveys allows us to investigate the relations between family structure and time use separately by country and gender. Second, because each of the surveys oversamples weekend reports, we can further disaggregate the analysis by weekdays and weekends. Third, the time diary nature of the data offer distinct advantages over data based on narrowly-structured activity recall questions. The diaries record all the primary activities in which people are engaged and who else is present during these activities. Thus, we are able to identify time spent on primary care activities - activities such as playing with a child or changing a diaper which are done for the direct benefit of a child - and time spent on passive care - other activities done with a child present that do not directly involve the child such as shopping - and time spent on market work.

For our multivariate analyses, we employ a system of correlated Tobit equations to model the time parents spend in primary child care, passive child care, and market work. The Tobit framework accounts for the modest proportions of people who report spending no time in each given activity on a particular day. We estimate correlated specifications because multiple uses of time are reported by every respondent and because each respondent's total daily time allotment is constrained to 24 hours. For the UKTUS, which records two diaries for each person and 
provides information for both parents in two-parent households, our estimation procedure further accounts for clustering from related reports. As discussed above, in estimating the time use equations we also allow for the possible endogeneity of the family structure.

The rest of this paper is organized as follows. We discuss conceptual models of time use, most notably the economic household production model, in the next section and briefly review previous studies on time allocation. We describe the ATUS and UKTUS data sets in Section III and discuss how we construct our measures and select our observations for the empirical analysis. In Section IV we present our econometric specification. Estimation results are reported and analyzed in Section V. Concluding remarks appear in Section VI.

\section{Literature Review}

The primary conceptual framework that we use to analyze the time that parents spend in child care and market work is Becker's (1965) time allocation, or household production, model. In Becker's model, people derive utility or satisfaction from household-produced goods such as their children's health, development, and well-being. A fundamental insight provided by this model is that the production and enjoyment of these outcomes require purchases of goods and services and contributions of time. Parents face a technological constraint, similar to the constraint faced by firms, on how inputs of goods and time can be combined to generate the desired outcomes. As in other consumer and labor models, parents also have constraints on their financial resources and time. The model assumes that parents rationally choose the amounts of time that they spend in different activities, including child care and market labor, and the amounts of goods that they purchase in order to maximize utility subject to the constraints they face. 
Within this framework, family structure could affect caregiving through a number of mechanisms. First, changes in family structure affect resources and needs. Adding an ablebodied adult through marriage or cohabitation increases the household's available time and money resources, which could increase the amount of caregiving, the purchase of care services, or both. Adding a child increases the household's need for care. Second, family structure affects the opportunities for specialization. With multiple household members, one person can focus on market work while another focuses on caregiving (Becker 1985). Marriages, by virtue of being longer lasting and more stable, are likely to promote higher levels of specialization than other relationships (Willis \& Michael 1994). Third, family structure might directly influence the production of well-being outcomes by affecting the levels of stability and stress in the household (see, e.g., Wu \& Martinson 1993) or by providing role models for children (see the discussion in Haveman \& Wolfe 1995). Fourth, family structure could affect the amount of conflict in the household. On the one hand, co-residence helps to reduce the coordination problems in caregiving (Weiss \& Willis 1985). On the other hand, adding a decision-maker to the household increases the opportunities for conflict. When we consider these mechanisms together, the net impact of family structure is ambiguous.

The role of gender can also be examined through the lens of the household production model. The model implies that specialization is likely to occur in households with two adults if there are increasing returns to time spent in household and market activities and the adults can share or transfer their resources and output (Becker 1985). Specialization could also be a reasonable strategy if there are fixed costs (Cogan 1980) or quasi-fixed costs (Oi 1962) of labor. The model, by itself, does not explain the sex-typing of tasks. However, it does suggest that small, initial differences in relative abilities or circumstances can lead to specialization. Thus, if 
women are brought up to have a slight advantage in caregiving or housework or, alternatively, if childbearing places them at a temporary disadvantage in the labor market, there could be profound gender differences in specialized activities. Discrimination in the labor market could also stimulate specialization.

An analysis of the time devoted to the market and to caregiving requires that such time be measured. A number of studies have relied on responses to survey questions intended to collect information on the "typical” frequency and duration of particular activities (e.g., Aldous et al. 1998 and Muller 1995). Yet, there may be problems with these measures because people tend to over-report time when answering questions about time use in surveys (Robinson 1985).

Overreporting is especially severe for tasks like child care that are performed as secondary activities (Robinson 1985, Fedick et al. 2003). Time-diary data suffer less from this recall bias than questionnaire data (Robinson 2002; Juster \& Stafford 1985, 1991; Robinson \& Bostrom 1994; and Marini \& Shelton 1993).

Even with time diary data, however, there exists some debate regarding the measurement of time. Many time diaries collect information on both primary and secondary activities. Some even collect information on a third simultaneous activity. Diaries also typically collect information on the identities of the other persons present during an activity. These details are especially important for measuring child care activities, which can range from physically caring for or interacting with a child to loose monitoring. Empirical research has tended to distinguish between two types of child care activities: primary child care, which involves direct interactions with or activities on behalf of a child, and passive child care, which encompasses all other activities performed in the presence of a child. ${ }^{1}$ Each type of care is important in its own right. Bianchi (2000) has argued that primary child care time is an important measure of quality time 
spent with children and that by this measure, there has been little change in child care time over time. At the same time, she reports that time spent in the presence of children does differ with the employment status of the mother. Mothers who work outside the home spend substantially less time in the presence of their children than do other mothers. There is no longitudinal data on the effect of different types of care on child outcomes, but Bianchi suggests that the mixed results regarding the impact of maternal employment on child outcomes could be attributed to the fact that working mothers do not spend substantially less time on the most important type of care, primary child care time.

The limited availability of time-diary data means that only a few economic studies of child care have employed such data. Kooreman and Kapteyn (1987) used U.S. time-diary data from the 1975-1981 Time Use Longitudinal Panel on married couples to estimate models of time spent in child care and other activities. They found that higher wages for fathers increased care provided by mothers, that mothers' provision of care did not respond to changes in their own wages, and that fathers' provision of care did not respond to changes in either's wages. Examining married parents from the same survey, Nock and Kingston (1988) regressed aggregate time with children and time spent in particular care activities against measures of mothers' and fathers' work schedules, reporting that mothers' employment, especially employment during after-school hours, decreased their time spent with children. However, the effects on children were partially mitigated because the reductions were concentrated in secondary, not primary, activities with children. They found little evidence that fathers compensated for mothers' employment by increasing their direct care activities or substituting among activities. 
Bryant and Zick (1996) used a larger U.S. sample of two-parent, two-child families and found that the hours that mothers spent in the market labor reduced the time that they devoted to child care, though this effect appeared mainly for older children. Like Nock and Kingston, they found little evidence that fathers compensated with more child care time of their own. Hallberg and Klevmarken (2003) used Swedish data on dual-earner, married and cohabiting couples to investigate the determinants of child care, instrumenting for the parents' wages and market time

and the children's time spent in external care. They found that the time a spouse spends in child care has a positive impact on own time spent in child care, that neither own nor spousal wages affect child care time, that own hours worked have a negative effect on own time spent in child care, and that spousal hours worked have a positive effect.

These studies all focus on couple households. Sandberg and Hofferth (2001), however, examined time spent in the presence of children and found that single-parent households spend substantially less time with children. Kalenkoski, Ribar, and Stratton (2005) used British data to jointly examine primary and secondary child care time as well as time in market work. They found that married and cohabiting parents allocate their time similarly while single parents spend more time on child care and less time in market work. This paper is an extension of the latter work to include U.S. data in addition to British data, to distinguish further between weekday and weekend days, and to control for the endogeneity of family structure.

\section{Data}

We use two survey data sets for our empirical analyses: the American Time Use Survey and the United Kingdom Time Use Survey. 
American Time Use Survey. The ATUS is an ongoing national survey that has been conducted monthly by the U.S. Bureau of the Census for the U.S. Bureau of Labor Statistics since January 2003. For this study we use data from 2003 and 2004. Subjects for the ATUS are drawn from households in their last month of participation in the Current Population Survey (CPS). One person aged 15 or over within most outgoing CPS households is randomly selected to participate in the ATUS. This individual is contacted by mail to inform them of their selection and of the pre-selected day of their ATUS telephone interview.

The interview begins by updating information obtained from the monthly CPS survey. Subjects are asked to identify who else lives in the household and to list the members' genders, ages, and relationships to the subject. The respondent is also asked questions regarding his/her individual characteristics such as employment, earnings, and demographic information. A short (24 hour), retrospective time diary describing how an individual spent his or her time is then collected using less scripted interviewing. Respondents describe what they were doing during the pre-selected day, and their responses are later coded into standardized activities. Information on the duration, location, and people present is collect for each recorded activity. These interviews are conducted every month of the year and every day of the week, with a higher proportion of interviews occurring on weekends to achieve an approximate balance between weekday and weekend reports.

In 2003 there were a total of 20,720 respondents to the ATUS, but in 2004 funding limitations reduced the sample to 13,973 . We merge these two samples but, because our focus is on parental child care, we exclude from our estimation sample the relatively small number of persons living in households with multiple families, households with same-sex couples, households where grandparents are the chief caregiver, households with roommates or borders 
under the age of 18, and households where a child's caregiver is unable to be determined due to the presence of other related or unrelated individuals in the household. As we are keenly interested in work issues, we also exclude respondents who were enrolled in school full time and those who were themselves or whose partners were at retirement age (age 62 or above). Finally, we delete observations with allocated data or with inconsistent demographic information between the CPS and ATUS surveys. These exclusions reduce our sample to 21,023 individuals, each living in a separate household. This sample is used to estimate family structure equations for parents' living arrangements and numbers of children in different age ranges. In our analyses of child care and market work, we further reduce the sample to 10,979 adults who are either parents of co-resident children under the age of 18 or the spouses or unmarried partners of parents.

United Kingdom Time Use Survey. The UKTUS is a national household-based study with multiple questionnaire and time diary components that was conducted in 2000-2001. Selected household heads or their partners filled out household questionnaires providing information on household income and composition. Every person aged 8 and older identified as a household member was then provided a questionnaire asking about his or her education, employment status, earnings, and other demographic information, as well as two time-diary questionnaires for pre-selected days. Filled out in the respondent's own words, the time diaries are later coded to identify standardized primary and secondary time activities, the location of the activities, and categorical responses regarding others present during the activities for every 10minute interval during two 24 hour periods: one weekday and one weekend day. In sum, the UKTUS obtained 20,981 time diaries from 11,664 people living in 6,414 households.

For our analysis sample we employ selection criteria that are as similar as possible to 
those used for the ATUS. Households with missing intrahousehold relationship data, people not reporting age or education, people younger than age 18, people who were themselves or were partnered with someone at or above retirement age (60 for women and 65 for men), and people who were still in school are dropped from the sample. Households living in Northern Ireland are also excluded as information regarding the local unemployment rate and urbanicity is unavailable for this sample. Finally, all households including multiple families or children whose caregivers can not be identified are excluded. The resulting sample consists of 6,848 individuals. This is the sample used to estimate the family structure equations. ${ }^{2}$ The time use sample is a subset of the family structure sample, consisting of people living with their own or their partner's children under the age of 18; it includes 4,998 diaries for 2,642 adults living in 1,597 households. ${ }^{3}$ The key differences between the U.S. and U.K. data sets are the availability of multiple diaries per respondent and diaries for both partners in the household from the U.K.

Time Use Variables. We focus our time-use analysis on three activities: primary child care, passive child care, and market work. Primary child care activities are coded from primary time use activity codes defined with respect to household children. These include physical care, reading, playing (including sports), talking/listening, helping/teaching, education and health related activities, and travel related to caring for or helping children. We construct our primary child care measure by summing up all minutes spent in these activities.

Our measure of passive care is constructed by summing up all remaining time spent with children aged 14 and under. Although generally we define a household with children as one having children below the age of 18, the 14 and under restriction is made necessary by the more limited categorical nature of the information on who else is present from the UKTUS. There is no category for household children age 15-17. Excluded from this measure is all time spent on 
primary child care and all time spent sleeping or working or in personal care activities. The latter restrictions are necessary because the presence of others is not reported for most such activities in the ATUS data. Our market work measure includes time spent at a job, time spent in work-related activities such as socializing that is part of a job, and time spent on travel related to work (not commuting time). The ATUS measure also includes time spent in other incomegenerating activities and time spent in security procedures related to work. Time spent searching or interviewing for jobs is not included in the market work measure for either sample. More detailed information on the sample and the activity classifications is available upon request.

We analyze time use separately by gender and by day of week, treating holidays like weekend days. Key conditioning variables are the respondent's living arrangement (married, cohabiting, or single), the number of other adults in the household, and the number of children in different age ranges (0-3, 4-6, 7-11, and 12-17) in the household. Other common controls include seasonal dummies (as time of year likely affects children's need for care), the age and education of the caregiver, and the unemployment rate of the locality. Dummy variables to identify region of residence, those residing in non-metro areas, diaries collected in 2004, and race and ethnicity are also incorporated in the U.S. specification. Dummy variables to identify those residing in rural areas and in London are included in the U.K. specification.

Descriptive Statistics. Table 1 reports the average daily minutes spent on primary child care, passive child care, and market work by gender (female/male), living arrangement (single, cohabiting, married), and day of the week (weekday/weekend). Panel A reports these statistics for the U.S. sample, while Panel B reports these statistics for the U.K. sample.

The numbers of diaries for each gender-day combination are substantial for both samples, exceeding 1,000 for each combination. The distributions by living arrangement are, however, 
quite different by country. Within our U.S. sample, about $71 \%$ of the women were married, $3 \%$ were cohabiting, and $26 \%$ were single. The corresponding numbers for men were roughly $90 \%$, $3 \%$, and $8 \%$. By contrast, in the U.K. sample, roughly four times as many parents were cohabiting ( $11 \%$ of the women and $13 \%$ of the men). A comparison of the U.K. sample distribution with statistics for the U.K. population at large indicates that this sample distribution is a close match for the population. ${ }^{4}$ A substantial fraction of the cross-country differences are driven by cross-country differences in cohabitation rates. National figures indicate that only $6 \%$ of all American children less than age 18 lived in households with unmarried partners in 2000 and this overstates the fraction living with cohabiting parents. ${ }^{5}$

A comparison of the time use measures reveals that gender differences are similar and substantial in both countries. Women spend over twice as much time on primary child care as men on weekdays. On weekends, they report spending over $40 \%$ more time than men in the U.S. and over 70\% more time than men in the U.K. Passive child care time is more evenly distributed across men and women on weekends, but is still predominantly a female activity on weekdays, when women report contributing over $60 \%$ more time than men. In both countries, women devote substantially less time than men to market work, somewhat more than half as much in the U.S. and somewhat less than half as much in the U.K. On average, on weekdays parents in the U.S. spend more time on primary child care and less time on passive care than parents in the U.K.

Descriptive statistics for the other variables used in the analysis are reported in Appendix A. A very important set of these variables includes the number of children in different age ranges. A somewhat greater fraction of households in our U.S. sample have children in the youngest age range (0-3) than in our British sample, and a greater fraction of the British sample 
has teenagers.

\section{Econometric Specification}

In our multivariate analyses we estimate systems of censored regression (Tobit) models of mothers' and fathers' daily allocations of time to primary child care, passive child care, and market work. Our use of a system approach is motivated by the fact that each person in our sample reports on several uses of time. Unmeasured person-specific characteristics, such as unmeasured needs, resources, abilities, or preferences, will lead to correlations in the daily reports. Correlations may also arise because the time allocations are non-overlapping and jointly constrained by the length of the day.

Our analyses focus on the relationships between parents' living arrangements (single, cohabiting, or married) and time use, and between the number and age distribution of their children and time use. Because parents' living arrangements and family sizes are behavioral outcomes, we consider the possibility of endogeneity bias when these outcomes are included as conditioning measures. Accordingly, we model these outcomes together with time use in a FullInformation Maximum Likelihood specification. Below, we describe the time use and family structure components of our system.

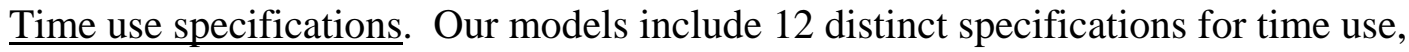
which are particular to the type of activity, the gender of the person performing it, and the type of day on which it occurs. For a given family, let $P_{g, d}, S_{g, d}$ and $H_{g, d}$ represent the daily minutes that parent or partner $g$ on day $d$ reports performing primary child care, passive child care, and market work activities, respectively (henceforth we refer to both parents and partners as “parents"). Parents are indexed by their gender, female $(g=f)$ or male $(g=m)$, and days are 
indexed by whether they are regular weekdays $(d=1)$ or weekends or holidays $(d=2)$.

All of the reported uses of time must be non-negative. To incorporate this constraint, we assume that that the actual reports are related to a set of continuous latent variables, $P_{g, d}^{*}, S_{g, d}^{*}$, and $H_{g, d}^{*}$, such that each of the reports equals the corresponding latent variable if the latent variable is positive and equals zero if the latent variable is zero or negative (e.g., $P_{g, d}=P_{g, d}^{*}$ if $P_{g, d}^{*}>0$ and $P_{g, d}=0$ otherwise). We then write our multivariate time use models in terms of the latent variables.

Let $L$ be a vector of measures describing the parent's living arrangements; let $K$ be a vector describing the number and age distribution of the children; let $X_{g, d}$ be a vector of other person- and day-specific measured characteristics; let $e_{P, g, d}, e_{S, g, d}$, and $e_{H, g, d}$ be random variables that represent unmeasured activity and person- and day-specific characteristics; and let $\alpha$, $\beta$, and $\gamma$ (with appropriate activity, gender and day subscripts) be vectors of coefficients. We assume that the latent time spent in each activity is a linear function of the observed and unobserved variables such that

$$
\begin{gathered}
P_{g, d}^{*}=\alpha_{P, g, d}^{\prime} L+\beta_{P, g, d}^{\prime} K+\gamma_{P, g, d}^{\prime} X_{g, d}+e_{P, g, d} \\
S_{g, d}^{*}=\alpha_{S, g, d}^{\prime} L+\beta_{S, g, d}^{\prime} K+\gamma_{S, g, d}^{\prime} X_{g, d}+e_{S, g, d} \\
H_{g, d}^{*}=\alpha_{H, g, d}^{\prime} L+\beta_{H, g, d}^{\prime} K+\gamma_{H, g, d}^{\prime} X_{g, d}+e_{H, g, d} .
\end{gathered}
$$

The specifications of these relationships, along with the specification of how actual minutes are reported conditional on the latent variables, describe a set of censored regression models. For each daily diary report for each parent in our sample, we jointly estimate all three models, allowing for correlations among the $e_{P, g, d}, e_{S, g, d}$, and $e_{H, g, d}$ terms.

Family structure models. Along with the time use models, we jointly estimate discrete- 
choice models of the determinants of people's living arrangements (elements of $L$ ) and of the number and age distribution of their children (elements of $K$ ). For living arrangements, we examine three outcomes: being single, cohabiting, and being married. Let $V_{S}^{*}, V_{C}^{*}$, and $V_{M}^{*}$ denote the indirect utilities associated with each of these outcomes. For convenience, we normalize $V_{S}^{*}=0$.

Let each of these indirect utilities be a linear function of observed family-specific variables, $Z$, and unobserved variables, $u_{C}$, and $u_{M}$, such that

$$
V_{C}^{*}=\delta_{C}^{\prime} Z+u_{C} \quad \text { and } \quad V_{M}^{*}=\delta_{M}^{\prime} Z+u_{M}
$$

where $\delta_{C}$ and $\delta_{M}$ are vectors of coefficients. We assume that people choose the living arrangement with the highest indirect utility.

For the number and age distribution of children, we assume that people have a latent, desired number of children in each of several age categories, which we denote $K_{j}^{*}$ where $j$ indexes the age categories. We consider four age categories—ages 0-3, ages 4-6, ages 7-11, and ages 12-17—with corresponding subscripts $j=1$, 4. We assume that each $K_{j}^{*}$ is a linear function of observed characteristics, $Z$, and unobserved characteristics, $w_{j}$, such that

$$
K_{j}^{*}=\psi_{j}^{\prime} Z+w_{j} .
$$

The actual number of children depends on $K_{j}^{*}$ being above or below different thresholds. For example, the number of children in the 0-3 (first) age category is given by

$$
K_{1}= \begin{cases}0 & \text { if } K_{1}^{*} \leq 0 \\ 1 & \text { if } 0<K_{1}^{*} \leq \tau_{1,1} \\ 2 \text { or more } & \text { if } \tau_{1,1}<K_{1}^{*}\end{cases}
$$

In these ordered categorical specifications, the coefficients, $\psi_{j}$, in the latent index equations and 
the thresholds, $\tau_{j, t}$, in the reporting models are estimated. In our models, the number of children aged 4-6 is similarly described by three categories, while the numbers of children aged 7-11 and 12-17 are described by four categories each.

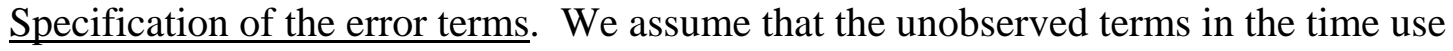
and family structure models are composites consisting of a common family-specific factor, $\mu$, and various outcome-specific components as follows

$$
\begin{array}{ll}
e_{a, g, d}=\lambda_{a, g, d} \mu+\varepsilon_{a, g, d} & \text { for } a=P, S, H ; g=f, m, \text { and } d=1,2 \\
u_{b}=\lambda_{b} \mu+v_{b} & \text { for } b=C, M \\
w_{j}=\lambda_{j} \mu+\eta_{j} & \text { for } j=1,4
\end{array}
$$

where the $\varepsilon, v$, and $\eta$ terms are the outcome-specific errors and the $\lambda$ terms are coefficients, or factor loadings, on the family-specific error. The presence of the common family-specific factor in the composite errors leads to correlations among the errors. In alternative specifications, we allow $\mu$ to follow either a discrete distribution, in which we estimate both points of support and their associated probabilities, or a normal distribution, in which we estimate the variance.

For each parent on each day, we allow for additional correlations in the unobserved determinants of their activities by allowing the activity-specific error components to be jointly normally distributed with an unrestricted covariance structure

$$
\left[\begin{array}{c}
\varepsilon_{P, g, d} \\
\varepsilon_{S, g, d} \\
\varepsilon_{H, g, d}
\end{array}\right] \sim N\left(\left[\begin{array}{l}
0 \\
0 \\
0
\end{array}\right],\left[\begin{array}{ccc}
\sigma_{P, g, d}^{2} & \rho_{P S, g, d} \sigma_{P, g, d} \sigma_{S, g, d} & \rho_{P H, g, d} \sigma_{P, g, d} \sigma_{H, g, d} \\
\rho_{P S, g, d} \sigma_{P, g, d} \sigma_{S, g, d} & \sigma_{S, g, d}^{2} & \rho_{S H, g, d} \sigma_{S, g, d} \sigma_{H, g, d} \\
\rho_{P H, g, d} \sigma_{P, g, d} \sigma_{H, g, d} & \rho_{S H, g, d} \sigma_{H, g, d} \sigma_{H, g, d} & \sigma_{H, g, d}^{2}
\end{array}\right]\right)
$$

This specification, which is akin to a Seemingly Unrelated Regressions framework, accounts for the overarching time constraint that may require individuals spending more time on one activity 
to spend less time on another. It also accounts for other similarities across the person's activity reports.

Beyond this, we assume that the error components are independent of one another and independent within and across families. We assume that the outcome-specific components of the model for living arrangements, $v_{C}$ and $v_{M}$, follow independent extreme-value distributions and that the outcome-specific components of the models for the number and ages of children, $\eta_{1}, \ldots$ $\eta_{4}$, follow independent standard normal distributions.

When all of the elements are put together, our model is a large recursive system with the different types of time use depending on family structure but not vice versa. Our time use specifications are estimated for parents, while the family structure equations are estimated for all adults. We account for the possible endogeneity of family structure and selectivity of parenthood in the time use models by estimating the time use and family structure models jointly while allowing for correlations in the unobserved determinants of these outcomes through the common factor $\mu$. The use of a factor-analytic specification restricts the error covariance matrix; however, the technique has the advantage of being computationally tractable and feasible. The system of equations is estimated using the aML software. ${ }^{6}$

\section{Results}

ATUS sample. Table 2 reports coefficient estimates and standard errors for selected parameters from the 12 Tobit time use models estimated using the ATUS data. Estimates for the remaining parameters from the time use models and parameters from the discrete-choice family structure models from our system are listed in Appendix B for this sample. 
Because of the complexity of our time use and family structure empirical system, we only report detailed results from one specification for each of our data sets. The specifications exactly conform to our descriptions from the previous section. Initial specification tests revealed that we could reject a simpler "exogenous" system that omitted a factor-analytic control. For the ATUS sample we experimented with normal and two-point discrete distributions for the unobserved factor $\mu$ before settling on a three-point discrete distribution. Initial tests also rejected specifications that omitted correlations between the uses of time for each person on each day. Where appropriate, we discuss differences between our reported results and these alternative specifications. Detailed results from the alternative specifications are available upon request.

In the table and appendix, the results for the time use models are organized in columns by activity (primary child care, passive child care, and market work) and within that by gender (women followed by men) and within that by weekday or weekend/holiday status. Likelihood ratio tests and the results in the first two rows of Table 2 indicate that parents' living arrangements are significantly associated with several time use outcomes. Married mothers in the U.S. are estimated to spend less time than single mothers in primary child care, passive child care and market work, with five of the six relevant coefficients being statistically significant. Married fathers are estimated to spend less time than single fathers on primary and passive child care and slightly more time on market work. However, only the coefficients on primary child care and weekday passive care are statistically distinguishable from zero. The results for fathers are potentially consistent with standard stories regarding specialization; however, the results for mothers are a little surprising. Married mothers appear to be specializing in other activities besides child care. 
The coefficients on cohabitation are much less precisely estimated than the coefficients on being married, with standard errors that are all about double those on the marriage coefficients. Nevertheless, there are some statistically significant results: cohabiting mothers spend less time than single mothers on weekend/holiday passive care and weekday market work, while cohabiting fathers spend less time than single fathers on weekday primary care. Further comparisons (not shown in the table) reveal that cohabiting mothers spend more time in weekend/holiday primary care than married mothers, while cohabiting fathers spend less time in weekday primary care than married fathers.

As expected, the number of young children is positively associated with the amount of time that American mothers and fathers spend on primary child care, with the associations being strongest for the youngest children. The number of young children is also positively associated with mothers' passive care and negatively associated with their market work on weekdays, again with stronger associations for younger children. The associations between young children and mothers' weekend passive care and market work are weaker. All of the coefficients for children in these models are statistically insignificant except for the positive coefficient on children 7-11 in the mothers' weekend passive care model and the negative coefficient on children 0-3 in the mothers' weekend market work model. Similarly, most of the children variables are statistically insignificant in the weekday and weekend/holiday models for fathers' passive care and market work. The significant coefficients are limited to the youngest children, who are positively associated with men's weekend/holiday passive care and negatively associated with their market work, and school-age children aged 7-11, who are positively associated with fathers' passive care and negatively with their weekday market work. 
The number of older school-age children, those aged 12-17 years, is negatively associated with parents' weekend/holiday provision of primary care. These older children may be helping with child care on non-school days. Interestingly, children aged 12-17 are positively associated with weekday passive care and negatively associated with weekday market work for women. Children in this age range are not strongly associated with fathers' passive care or market work.

Having additional adults in the household appears to reduce parental time spent on child care. For primary care, the associations are significant for mothers' weekday care and fathers' weekend/holiday care. For passive care, the associations are significant for both genders on weekdays and weekends/holidays. These results are consistent with other adults in the household acting as substitute caregivers, particularly as regards passive care. Mothers are estimated to work more on weekdays for each additional adult, perhaps because these adults free them from some child care responsibilities or perhaps because there is a greater need for household income in order to help provide for the other adult.

Education also appears to be an important determinant of time use in the U.S. More educated parents are estimated to spend more time on both primary child care and market work than less educated parents. These results are especially interesting because, as with Bianchi's (2000) findings that primary child care time has increased somewhat over time as women’s work hours have risen, they indicate that better job opportunities do not necessarily come at the expense of child care time. More educated parents appear to find a way to work more yet also provide more child care time.

There are numerous other control variables in our time use models. Because these variables are not central to our analyses, we do not discuss most of them in detail. One unexpected set of results, however, does merit some additional discussion. Among the seasonal 
dummies, we find that mothers and fathers provide less weekday primary care during the summers than at other times. Mothers also provide less weekend/holiday primary care during summers. The decrease in primary care appears to be balanced by an increase in passive care. Mothers also report working less in the summer. Given that school is out and more children are home during the weekdays in the summer, we expected to observe an increase in primary care time. These results may reflect more outdoor play by children and less direct interaction by adults (certainly less time helping with homework). They could also reflect time spent with children being reported as recreational activities instead of primary child care.

A distinguishing feature of our empirical approach is the use of a discretely distributed unobserved factor to account for the endogeneity of parents' living arrangements and the numbers and ages of their children. Appendix B reports estimates of the locations of the three points of support for the discrete distribution along with transformed values of the associated probabilities. $^{7}$ To better show the estimated distribution, we calculated the actual probabilities, centered the mean of the distribution at zero, and graphed the results. The resulting distribution is shown in the top panel of Figure 1. The distribution is single-peaked but skewed and asymmetric; thus, the shape is very different from the discrete approximation to a normal distribution. Indeed, a formal specification test rejected the Gauss-Hermite approximation of the normal with three points of support.

The coefficients on the unobserved factor in the family structure models (reported in Appendix B) are all positive, indicating that higher values of the factor are associated with greater likelihoods of marriage over cohabitation and of cohabitation over singlehood and with larger numbers of children. The corresponding coefficients in the time use equations in Table 2 are also positive. Thus, unobserved characteristics that are associated with stronger unions and 
larger families are also associated with greater inputs of time into child care and market work. Models that fail to account for this positive selection show estimates of the effects of marriage, cohabitation, and numbers of children that are all biased upward.

UKTUS sample. Results from the time use and family structure system estimated using the UKTUS sample are arrayed the same way as the results using the ATUS sample, with the main coefficients of interest from the 12 time use models reported in Table 3 and the remaining time use coefficients and all of the family structure coefficients reported in Appendix C. As with the ATUS results, we only report detailed estimates from one specification as specification tests rejected simpler models. The final UKTUS model includes a discretely distributed unobserved factor with five points of support.

The first controls in Table 3 are for living arrangements. Many of the estimated associations between living arrangements and child care activities are similar across the two countries and as in the U.S., the associations are jointly significant. Married mothers and cohabiting fathers in both countries spend less time in primary child care on weekdays than their single counterparts. The estimated coefficients for marriage in the weekend/holiday primary care model for mothers and the weekday primary care model for fathers are also negative, though not statistically distinguishable from zero. Also like the U.S., both married mothers and fathers in the U.K. spend less time in passive care than their single counterparts.

Some of the biggest differences between the U.S. and the U.K. results appear in the market work models. While married and cohabiting mothers in the U.S. work less than single mothers, married and cohabiting mothers in the U.K. work more. On weekdays, married and cohabiting fathers in the U.K. also work more than single fathers. The profound differences in market work behavior may reflect differences in social policy between the two countries. In 
particular, assistance policies in the U.K. at the time of the survey supported and even encouraged single parents to stay at home and care for their children while welfare-to-work requirements in the U.S. did just the opposite (Walker and Wiseman 2003).

As in the U.S., additional young children, especially those aged six and under, increase time spent by parents in primary care on weekdays and weekends/holidays. Very young children increase the time that mothers devote to passive care on weekdays. Children 7-11 also increase the time that mothers and fathers spend on this activity on weekdays. These results and the finding that young children are associated with reductions in weekday market work are also like those from the U.S. data. Infants appear to reduce weekend market work for women but not men in the U.K.

Children aged 12-17 are more strongly negatively associated with primary care in the U.K. than the U.S., again consistent with both their needing less care and possibly providing care of their own. As in the U.S., the presence of other adults in the household negatively affects parents' child care time, suggesting that these other adults act as substitute caregivers. However, the timing and type of the reduction in child care time each differ. For example, mothers' time in primary care is reduced on the weekend rather than on the weekday as in the U.S. Also, both mothers' and fathers' passive care is reduced only on the weekend, not on all days as in the U.S. Unlike in the U.S., an additional adult does not significantly affect either parent's market work time. In general, other adults appear to be somewhat lesser and older children somewhat stronger substitutes for parental child care in the U.K. than in the U.S.

Education does not appear to be nearly as important a determinant of child care time in the U.K. as in the U.S. In Table 3, nearly all of the education coefficients in the primary care models are insignificant and close to zero. The coefficients in the passive care models are larger, 
though generally insignificant and of varying signs. As in the U.S., education in the U.K. is positively associated with mothers’ weekday market work. Unlike the U.S., education in the U.K. is only modestly associated with fathers’ weekday market work and is negatively associated with their weekend work.

We also observe some of the same seasonal patterns in the U.K. as in the U.S. In particular, women's weekday primary care and market work falls during the summer, while their weekday passive care increases. This again is consistent with a recategorization of time spent with children away from direct caregiving and toward recreational activities during the summer months.

The estimated adjustments for endogeneity are somewhat different in the U.K. than the U.S. The discrete distribution for the unobserved factor in the UKTUS data is described by five points. We believe that we were able to fit more points for the distribution in the U.K. because the UKTUS contains repeated observations for households and for people within households. As shown at the bottom of Figure 1, the distribution for the unobserved factor in the U.K. is asymmetric and dual-peaked, with a standard deviation that is nearly double that of the unobserved factor in the U.S.

As in the U.S., the unobserved common factor in the U.K. represents characteristics associated with stronger unions and more children. While the factor loads positively into primary care activities and especially into passive care activities, it has almost no association with market work activities. Thus, the factor appears to mitigate positive biases in the estimated associations between family structure and child care time. However, there is little evidence of endogeneity bias in the estimated association between family structure and market work time. 
Marginal effects. Coefficient estimates from nonlinear models such as these are difficult to interpret especially across samples. To provide interpretable magnitudes for our model results, we calculated marginal effects for our estimated family structure coefficients in Tables 2 and 3 using Monte Carlo simulation techniques. We report these results for the ATUS in the top panel of Table 4 and report results for the UKTUS in the bottom panel. For each sample, the marginal impacts of couple status were obtained by comparing predicted time use assuming everyone was married (or cohabiting) with similar predictions assuming everyone was single. Marginal effects of the numbers of children and adults were determined by incrementing the relevant explanatory variable by one unit for each person and comparing predicted time use across the sample before and after the change.

The first two rows of each panel in Table 4 list the marginal effects associated with parents' living arrangements. Here one can clearly see that cohabitation and marriage reduce time spent on primary child care almost across the board relative to single parenthood in both the U.S. and the U.K., but the magnitude of the difference is typically quite small. The differences are more substantial (often about 30 minutes) with respect to passive care and reach as high as 90 minutes for men in the U.K. on weekdays. The most striking cross-country differences in the effect of marriage and cohabitation on time use are on market work time. While married and cohabiting women in the U.S. spend less time on paid employment than their single counterparts on both weekdays and weekends, married and cohabiting women in the U.K. spend more time than their single counterparts. The net difference is about 2 hours per day on weekdays and a half hour per day on weekends for both partner types. The difference in the marginal effects of marital and cohabitation status as compared to single parenthood on weekdays for men between these two countries is also substantial, amounting to almost 3 hours per day. Some, but not all, 
of this time appears to be spent on passive child care. The marginal effects of marriage and cohabitation compared to remaining single are quite similar between countries. Single parents in the U.S. clearly engage in significantly more market work than their U.K. counterparts who generally spend some more time on passive care.

The marginal effects of additional children of different ages are also reported in Table 4. Children aged three years and less make the most difference in time allocations, increasing time spent on primary child care and, for women, decreasing time spent on employment. The effect of children of different ages on passive child care (and on employment for men) shows a less consistent pattern. In both the U.S. and the U.K. the effect on child care of older children (ages 12-17) and other adults is often negative, suggesting that they may play some role as alternative caregivers.

\section{Conclusion}

In this paper we investigate the determinants of parental time investments in primary child care activities, passive child care activities, and market work using newly-available timediary data from the 2003 and 2004 American Time Use Study (ATUS) and data from the 2000 United Kingdom Time Use Study (UKTUS). We focus in particular on the effects of parents' living arrangements (married, cohabiting, or single) because most previous economic studies using time diary data have analyzed only two-parent families. Furthermore, we allow parents' living arrangements to be endogenously determined. We then ask how whether a child lives with a single parent or with married or cohabiting parents affects the allocation of time to child care and to employment by each of his or her parents. Due to the richness of the data, we are able to 
examine this question separately by the gender of the caregiver and by whether or not the activities occur on a non-holiday weekday or holiday/weekend day.

We estimate correlated Tobit models of the time parents spend in primary child care, passive child care, and market work, while simultaneously controlling for the endogenous nature of both the family living arrangements and the number and ages of the children. These models account for reports of multiple uses of time in a day by a single individual and, for the UKTUS sample, reports for multiple days per family. In conclusion, we find little evidence that cohabiting and married parents allocate time differently either between or within countries, but substantial evidence that single parenthood has a substantially different effect on time allocations. Single parents in both the U.K. and the U.S. spend somewhat more time on both primary and passive child care than their partnered counterparts. However, while both single mothers and single fathers in the U.K. spend substantially less time in market work (particularly on weekdays) compared to their partnered counterparts, single mothers and fathers in the U.S. spend substantially more time. We believe that this differential may be attributed to crosscountry differences in the welfare system which at the time these data were collected was more supportive of stay-at-home parents in the U.K. and more supportive of employed parents in the U.S. Our results regarding the impact of parental living arrangements on child care time are of substantial interest. They suggest, however, that further research on the degree to which parental time overlaps and single parents are aided by non-household parents, as well as research on the relative effect primary child care time versus passive child care time has upon children's outcomes would make a valuable contribution to our understanding of how children and society are affected by the time allocation decisions of parents. 


\section{References}

Aldous, Joan, Gail Mulligan, and Thoroddur Bjarnason. "Fathering over Time: What Makes the Difference?” Journal of Marriage and the Family 60 (November 1998): 809-820.

Amato, Paul, and Fernando Rivera. "Paternal Involvement and Children’s Behavior Problems.” Journal of Marriage and the Family 61 (May 1999): 375-384.

Becker, Gary. “A Theory of the Allocation of Time.” Economic Journal 75 (September 1965): 493-517.

Becker, Gary. A Treatise on the Family. Cambridge, MA: Harvard University Press, 1981.

Becker, Gary. “Human Capital, Effort, and the Sexual Division of Labor.” Journal of Labor Economics 3 (January 1985, part 2): S33-S58.

Bianchi, Suzanne M. "Maternal Employment and Time with Children: Dramatic Change or Surprising Continuity?” Demography 37 (November 2000): 401-414.

Bryant, W. Keith, and Cathleen Zick. “An Examination of Parent-Child Shared Time.” Journal of Marriage and the Family 58 (February 1996): 227-237.

Cogan, John. “Labor Supply with Costs of Labor Market Entry,” in Female Labor Supply: Theory and Estimation, James Smith (ed.). Princeton: Princeton University Press, 1980: $327-364$.

Datcher-Loury. “Effects of Mother’s Home Time on Children’s Schooling.” Review of Economics and Statistics 70 (August 1988): 367-373.

Fedick, Cara B., Shelley Pacholok and Anne H. Gauthier. "Methodological Issues Related to the Measurement of Parental Time.” Unpublished manuscript. July 2003. 
Folbre, Nancy, Jayoung Yoon, Kade Finnoff, and Allison Sidle Fuligni. "By What Measure?:

Family Time Devoted to Children in the United States”. Demography 42(2) (May 2005): 373-390.

Gupta, Sanjiv. “The Effects of Transitions in Marital Status on Men’s Performance of Housework.” Journal of Marriage and the Family 61 (August 1999): 700-711.

Hallberg, Daniel and Anders Klevmarken. “Time for Children: A Study of Parent’s Time Allocation.” Journal of Population Economics 16 (2003): 205-226.

Haveman, Robert, and Barbara Wolfe. “The Determinants of Children’s Attainments: A Review of Methods and Findings.” Journal of Economic Literature 33 (December 1995): 18291878.

Juster, F. Thomas, and Frank Stafford. Time, Goods, and Well-Being. Ann Arbor, Michigan: The University of Michigan, 1985.

Juster, F. Thomas, and Frank Stafford. “The Allocation of Time: Empirical Findings, Behavioral Models, and Problems of Measurement.” Journal of Economic Literature 29 (June 1991): 471-522.

Kalenkoski, Charlene, David Ribar, and Leslie S. Stratton. "Parental Child Care in Single Parent, Cohabiting, and Married Couple Families: Time Diary Evidence from the United Kingdom.” American Economic Review Papers and Proceedings. Forthcoming May 2005.

Kooreman, Peter, and Arie Kapteyn. “A Disaggregated Analysis of the Allocation of Time within the Household.” Journal of Political Economy 95 (April 1987): 223-249.

Marini, M.M., and B.A. Shelton. "Measuring Household Work: Recent Empirical Experience in the United States.” Social Science Research 22 (1993): 361-382. 
McLanahan, Sara, and Gary Sandefur. Growing Up with a Single Parent. Cambridge, MA: Harvard University Press, 1994.

Muller, Chandra. "Maternal Employment, Parent Involvement, and Mathematics Achievement among Adolescents.” Journal of Marriage and the Family 57 (February 1995): 85-100.

Nock, Steven, and Paul Kingston. “Time with Children: The Impact of Couples’ Work-Time Commitments.” Social Forces 67 (September 1988): 59-85.

Oi, Walter. “Labor as a Quasi-fixed Factor.” Journal of Political Economy (December 1962): 538-555.

Robinson, J.P. "The Time-Diary Method: Structure and Uses,” in Time Use Research in the Social Sciences, W. Pentland, A. Harvey, M. Powell Lawton, and M.A. McColl (eds.) New York: Kluwer Academic Publishers, 2002.

Robinson, J.P., and A. Bostrom. “The Overestimated Workweek? What Time Diary Measures Suggest.” Monthly Labor Review (1994): 11-23.

Robinson, John P. “The Validity and Reliability of Diaries versus Alternative Time Use Measures..” In Time, Goods, and Well-Being, eds. F. Thomas Juster and Frank P. Stafford. Ann Arbor, Michigan: Survey Research Center, Institute for Social Research, University of Michigan, 1985: 33-62.

Sandberg, John F. and Sandra L. Hofferth. “Changes in Children’s Time with Parents, U.S. 1981-1997.” PSC Research Report \#01-475. May 2001.

South, Scott J., and Glenna Spitze. "Housework in Marital and Nonmarital Households.” American Sociological Review 59 (June 1994): 327-347. 
Stratton, Leslie S. "Gains from Trade and Specialization: The Division of Work in Married Couple Households,” in Women, Family, and Work, Karine S. Moe (ed.). Oxford: Blackwell Publishers, 2003.

Waite, Linda, and Maggie Gallagher. The Case for Marriage: Why Married People Are Happier, Healthier, and Better Off Financially. New York: Broadway Books, 2000.

Walker, Robert and Michael Wiseman, Editors. The Welfare We Want? The British Challenge for American Reform. Bristol, U.K.: Policy Press, 2003.

Weiss, Yoram and Robert J. Willis. “Children as Collective Goods and Divorce Settlements.” Journal of Labor Economics 3 (July 1985): 268-292.

Willis, Robert J. and Robert T. Michael. “Innovation in Family Formation: Evidence on Cohabitation in the United States.” in The Family, the Market and the State in Ageing Societies. John Ermisch and Neohiro Ogawa (eds.). Oxford: Clarendon Press, 1994: 9-45.

Wu, Lawrence L., and Brian C. Martinson. “Family Structure and the Risk of a Premarital Birth.” American Sociological Review 58 (April 1993): 210-32. 
Figure 1. Estimated Distributions of Unobserved Factors from Time Use and Family Structure Models

3-point Finite Mixture Distribution (ATUS)

(std. dev. = 1.05)

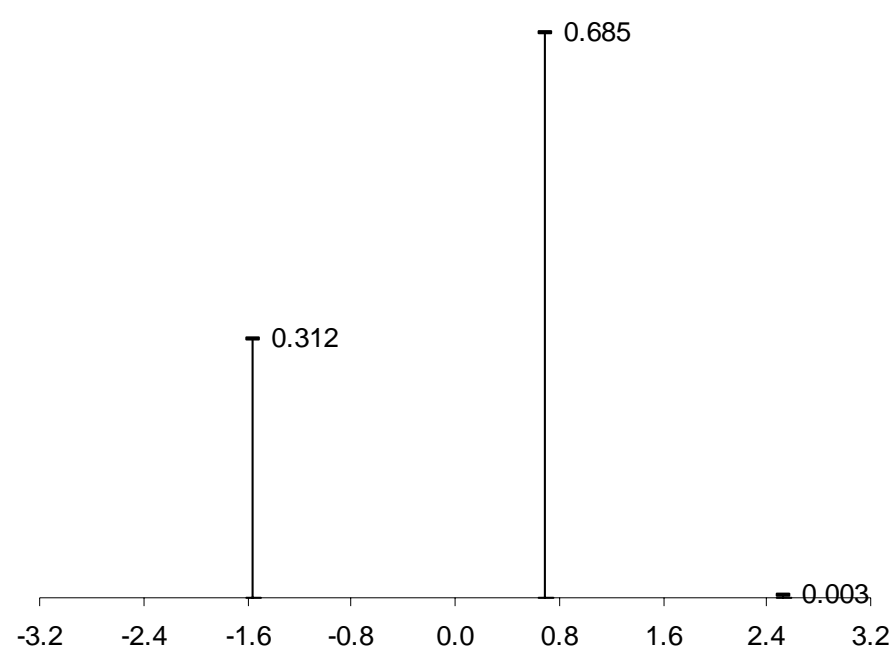

5-point Finite Mixture Distribution (UKTUS)

(std. dev. = 1.94)

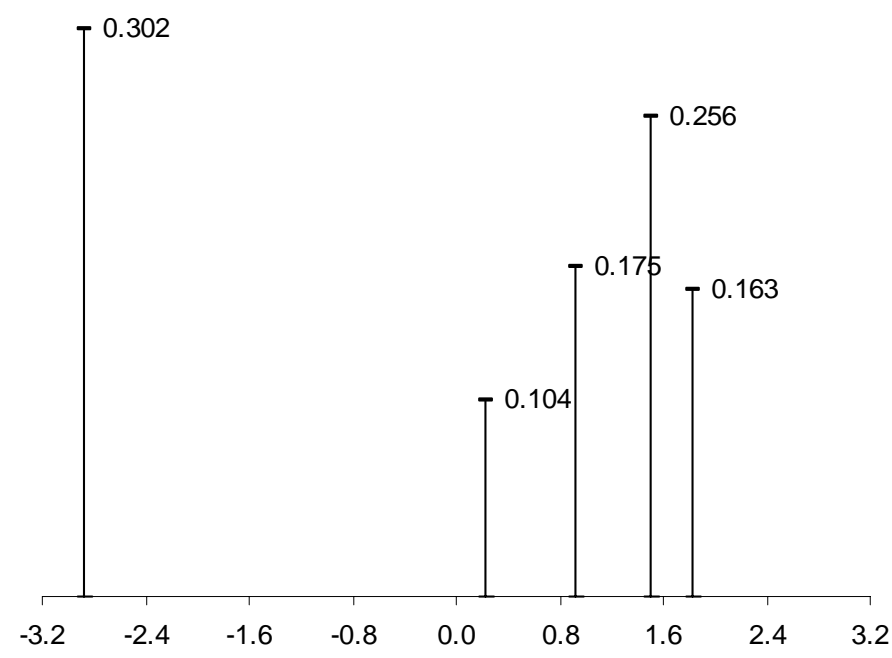

Note: Distributions are based on estimates reported in Appendices B and C. In the figures, the estimated points of support for each distribution are shown along the $\mathrm{X}$-axis, with the points being rescaled so that the means of the distributions are centered at zero. The probabilities associated with each point are shown by the height and labels of the bars. 
Table 1

Average Minutes Spent on Child Care and Employment by Gender, Living Arrangement, Day of Week, and Country

Panel A: United States

\begin{tabular}{|c|c|c|c|c|c|c|c|c|c|}
\hline & & \multicolumn{4}{|c|}{ Women } & \multicolumn{4}{|c|}{ Men } \\
\hline & & \multirow[b]{2}{*}{ All } & \multicolumn{3}{|c|}{ Living Arrangement } & \multirow[b]{2}{*}{ All } & \multicolumn{3}{|c|}{ Living Arrangement } \\
\hline & & & Single & Cohabiting & Married & & Single & Cohabiting & Married \\
\hline Weekday & $\begin{array}{l}\text { Primary } \\
\text { Child } \\
\text { Care Time }\end{array}$ & 130 & 105 & 122 & 139 & 60 & 69 & 37 & 60 \\
\hline & $\begin{array}{l}\text { Passive } \\
\text { Child } \\
\text { Care Time }\end{array}$ & 209 & 182 & 228 & 218 & 129 & 124 & 164 & 128 \\
\hline & $\begin{array}{l}\text { Work } \\
\text { Time }\end{array}$ & 249 & 296 & 222 & 233 & 440 & 378 & 353 & 448 \\
\hline & \# of Obs. & 3172 & 820 & 114 & 2238 & 2242 & 176 & 54 & 2012 \\
\hline & $\%$ of Obs. & $100 \%$ & $25.9 \%$ & $3.6 \%$ & $70.6 \%$ & $100 \%$ & $7.9 \%$ & $2.4 \%$ & $89.7 \%$ \\
\hline Weekend & $\begin{array}{l}\text { Primary } \\
\text { Child } \\
\text { Care Time }\end{array}$ & 93 & 70 & 98 & 101 & 65 & 36 & 62 & 68 \\
\hline & $\begin{array}{l}\text { Passive } \\
\text { Child } \\
\text { Care Time }\end{array}$ & 352 & 329 & 326 & 361 & 316 & 232 & 280 & 325 \\
\hline & $\begin{array}{l}\text { Work } \\
\text { Time }\end{array}$ & 59 & 78 & 46 & 53 & 108 & 85 & 125 & 109 \\
\hline & \# of Obs. & 3187 & 835 & 83 & 2269 & 2378 & 181 & 74 & 2123 \\
\hline & \% of Obs. & $100 \%$ & $26.2 \%$ & $2.6 \%$ & $71.2 \%$ & $100 \%$ & $7.6 \%$ & $3.1 \%$ & $89.3 \%$ \\
\hline
\end{tabular}


Table 1 - Continued

\section{Panel B: United Kingdom}

\begin{tabular}{|c|c|c|c|c|c|c|c|c|c|}
\hline & & \multicolumn{4}{|c|}{ Women } & \multicolumn{4}{|c|}{ Men } \\
\hline & & \multirow[b]{2}{*}{ All } & \multicolumn{3}{|c|}{ Living Arrangement } & \multirow[b]{2}{*}{ All } & \multicolumn{3}{|c|}{ Living Arrangement } \\
\hline & & & Single & Cohabiting & Married & & Single & Cohabiting & Married \\
\hline \multirow[t]{5}{*}{ Weekday } & $\begin{array}{l}\text { Primary } \\
\text { Child } \\
\text { Care Time }\end{array}$ & 109 & 113 & 130 & 104 & 39 & 51 & 38 & 38 \\
\hline & $\begin{array}{l}\text { Passive } \\
\text { Child } \\
\text { Care Time }\end{array}$ & 280 & 295 & 311 & 271 & 162 & 254 & 158 & 160 \\
\hline & $\begin{array}{l}\text { Work } \\
\text { Time }\end{array}$ & 191 & 148 & 184 & 205 & 411 & 248 & 399 & 418 \\
\hline & \# of Obs. & 1420 & 297 & 146 & 977 & 1070 & 30 & 137 & 903 \\
\hline & $\%$ of Obs. & $100 \%$ & $20.92 \%$ & $10.28 \%$ & $68.80 \%$ & $100 \%$ & $2.80 \%$ & $12.80 \%$ & $84.39 \%$ \\
\hline \multirow[t]{5}{*}{ Weekend } & $\begin{array}{l}\text { Primary } \\
\text { Child } \\
\text { Care Time }\end{array}$ & 81 & 72 & 113 & 79 & 47 & 19 & 59 & 46 \\
\hline & $\begin{array}{l}\text { Passive } \\
\text { Child } \\
\text { Care Time }\end{array}$ & 374 & 363 & 395 & 374 & 317 & 304 & 304 & 320 \\
\hline & $\begin{array}{l}\text { Work } \\
\text { Time }\end{array}$ & 53 & 45 & 48 & 57 & 109 & 120 & 133 & 105 \\
\hline & \# of Obs. & 1441 & 299 & 154 & 988 & 1067 & 31 & 146 & 890 \\
\hline & $\%$ of Obs. & $100 \%$ & $20.75 \%$ & $10.69 \%$ & $68.56 \%$ & $100 \%$ & $2.91 \%$ & $13.68 \%$ & $83.41 \%$ \\
\hline
\end{tabular}


Table 2 Selected Coefficient Estimates fromCorrelated Tobit Models of Time-Use: ATUS Sample

\begin{tabular}{|c|c|c|c|c|c|c|c|c|c|c|c|c|}
\hline & \multicolumn{4}{|c|}{ Daily Minutes of Primary Child Care } & \multicolumn{4}{|c|}{ Daily Minutes of Passive Child Care } & \multicolumn{4}{|c|}{ Daily Minutes of Market Work } \\
\hline & \multicolumn{2}{|c|}{ Women } & \multicolumn{2}{|c|}{ Men } & \multicolumn{2}{|c|}{ Women } & \multicolumn{2}{|c|}{ Men } & \multicolumn{2}{|c|}{ Women } & \multicolumn{2}{|c|}{ Men } \\
\hline & Weekday & Weekend & Weekday & Weekend & Weekday & Weekend & Weekday & Weekend & Weekday & Weekend & Weekday & Weekend \\
\hline Cohabiting & $\begin{array}{l}-16.7 \\
(13.7)\end{array}$ & $\begin{array}{c}8.7 \\
(15.0)\end{array}$ & $\begin{array}{l}-98.1 * * \\
(21.3)\end{array}$ & $\begin{array}{c}-7.6 \\
(28.0)\end{array}$ & $\begin{array}{c}0.3 \\
(18.9)\end{array}$ & $\begin{array}{l}-60.1 * \\
(32.4)\end{array}$ & $\begin{array}{l}-31.6 \\
(26.0)\end{array}$ & $\begin{array}{l}-33.9 \\
(44.7)\end{array}$ & $\begin{array}{c}-106.6 * * \\
(43.4)\end{array}$ & $\begin{array}{c}-102.1 \\
(82.0)\end{array}$ & $\begin{array}{l}-49.6 \\
(43.9)\end{array}$ & $\begin{array}{c}71.1 \\
(82.2)\end{array}$ \\
\hline Married & $\begin{array}{c}-14.9 \text { ** } \\
(6.3)\end{array}$ & $\begin{array}{l}-22.5 \text { **** } \\
(7.4)\end{array}$ & $\begin{array}{l}-61.4 \text { *** } \\
(11.2)\end{array}$ & $\begin{array}{l}-38.6 * * \\
(18.8)\end{array}$ & $\begin{array}{r}-14.2 \\
(9.9)\end{array}$ & 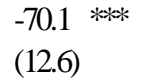 & $\begin{array}{l}-68.0 \\
(16.8)\end{array}$ & $\begin{array}{l}-35.6 \\
(27.3)\end{array}$ & $\begin{array}{l}-129.9 * * * * \\
(21.5)\end{array}$ & $\begin{array}{l}-92.6 \text { *1* } \\
(31.4)\end{array}$ & $\begin{array}{r}9.6 \\
(27.5)\end{array}$ & $\begin{array}{c}26.8 \\
(54.3)\end{array}$ \\
\hline Children 0-3 & $\begin{array}{l}88.0 * \\
(4.2)\end{array}$ & $\begin{array}{l}86.8 \\
(4.5)\end{array}$ & $\begin{array}{l}33.9 * * * \\
(5.5)\end{array}$ & $\begin{array}{l}75.2 * * \\
(7.1)\end{array}$ & $\begin{array}{l}71.0 * * * \\
(6.9)\end{array}$ & $\begin{array}{c}0.9 \\
(9.4)\end{array}$ & $\begin{array}{c}8.7 \\
(8.2)\end{array}$ & $\begin{array}{c}23.0 * \\
(12.7)\end{array}$ & $\begin{array}{l}-158.5 \text { *** } \\
(16.1)\end{array}$ & $\begin{array}{l}-79.4 \text { *** } \\
(24.9)\end{array}$ & $\begin{array}{l}-28.6 * * \\
(13.6)\end{array}$ & $\begin{array}{l}-51.7 * * \\
(24.5)\end{array}$ \\
\hline Children 4-6 & $\begin{array}{l}43.6 \text { * } \\
(4.1)\end{array}$ & $\begin{array}{l}34.6 \text { *** } \\
(5.1)\end{array}$ & $\begin{array}{l}26.2 * * * \\
(5.3)\end{array}$ & $\begin{array}{l}38.0 * * * \\
(6.9)\end{array}$ & $\begin{array}{l}40.0 \text { *** } \\
(6.9)\end{array}$ & $\begin{array}{l}-5.1 \\
(9.7)\end{array}$ & $\begin{array}{l}12.7 \\
(7.9)\end{array}$ & $\begin{array}{r}5.4 \\
(12.9)\end{array}$ & $\begin{array}{l}-104.7 * * * * \\
(15.3)\end{array}$ & $\begin{array}{c}-5.4 \\
(26.4)\end{array}$ & $\begin{array}{c}-3.6 \\
(13.7)\end{array}$ & $\begin{array}{c}10.5 \\
(23.8)\end{array}$ \\
\hline Children 7-11 & $\begin{array}{l}23.1 \text { *1k } \\
(3.5)\end{array}$ & $\begin{array}{c}2.4 \\
(3.9)\end{array}$ & $\begin{array}{l}9.1 * * \\
(4.2)\end{array}$ & $\begin{array}{l}13.4 \text { ** } \\
(5.6)\end{array}$ & $\begin{array}{l}45.8 \text { *kok } \\
(5.4)\end{array}$ & $\begin{array}{l}23.1 \\
(7.2)\end{array}$ & $\begin{array}{l}17.3 \\
(6.0)\end{array}$ & $\begin{array}{l}45.2 \text { **** } \\
(9.5)\end{array}$ & $\begin{array}{l}-85.7 \\
(12.1)\end{array}$ & $\begin{array}{l}-25.4 \\
(18.2)\end{array}$ & $\begin{array}{l}-28.4 * k \\
(10.3)\end{array}$ & $\begin{array}{l}-22.7 \\
(18.3)\end{array}$ \\
\hline Children 12-17 & $\begin{array}{c}1.6 \\
(3.9)\end{array}$ & $\begin{array}{l}-13.0 * * * \\
(4.2)\end{array}$ & $\begin{array}{l}-2.8 \\
(4.3)\end{array}$ & $\begin{array}{l}-18.6 * * * \\
(6.0)\end{array}$ & $\begin{array}{l}17.0 * * * \\
(6.0)\end{array}$ & $\begin{array}{l}-2.8 \\
(7.9)\end{array}$ & $\begin{array}{l}-4.0 \\
(6.9)\end{array}$ & $\begin{array}{c}4.4 \\
(10.1)\end{array}$ & $\begin{array}{l}-33.9 * * * \\
(12.5)\end{array}$ & $\begin{array}{c}22.0 \\
(20.0)\end{array}$ & $\begin{array}{c}7.6 \\
(10.8)\end{array}$ & $\begin{array}{l}-14.5 \\
(18.6)\end{array}$ \\
\hline Other Adults & $\begin{array}{l}-19.5 * * * * \\
(5.5)\end{array}$ & $\begin{array}{l}-0.4 \\
(5.7)\end{array}$ & $\begin{array}{l}-3.9 \\
(5.4)\end{array}$ & $\begin{array}{l}-30.4 * * * \\
(10.2)\end{array}$ & $\begin{array}{l}-20.1 * * \\
(8.6)\end{array}$ & $\begin{array}{l}-33.5 * * * \\
(10.0)\end{array}$ & $\begin{array}{c}-13.9 * \\
(8.3)\end{array}$ & $\begin{array}{l}-37.4 * * * \\
(13.9)\end{array}$ & $\begin{array}{l}29.1 * \\
(16.6)\end{array}$ & $\begin{array}{c}29.3 \\
(25.3)\end{array}$ & $\begin{array}{c}-1.1 \\
(14.6)\end{array}$ & $\begin{array}{c}10.7 \\
(28.5)\end{array}$ \\
\hline $\begin{array}{l}\text { High School } \\
\text { Graduate }\end{array}$ & $\begin{array}{l}18.8 * * \\
(8.8)\end{array}$ & $\begin{array}{l}23.1 * * \\
(10.6)\end{array}$ & $\begin{array}{l}33.3 * * * \\
(11.1)\end{array}$ & $\begin{array}{l}31.9 * * \\
(15.3)\end{array}$ & $\begin{array}{c}-7.7 \\
(13.5)\end{array}$ & $\begin{array}{l}-23.5 \\
(16.8)\end{array}$ & $\begin{array}{c}-9.0 \\
(14.2)\end{array}$ & $\begin{array}{l}-30.3 \\
(23.5)\end{array}$ & $\begin{array}{l}130.8 * * * * \\
(29.1)\end{array}$ & $\begin{array}{c}55.0 \\
(50.0)\end{array}$ & $\begin{array}{l}54.2 * * \\
(23.8)\end{array}$ & $\begin{array}{l}133.6 * * * \\
(47.3)\end{array}$ \\
\hline College + Graduate & $\begin{array}{l}42.0 * * \\
(9.6)\end{array}$ & $\begin{array}{l}64.9 * * \\
(11.6)\end{array}$ & $\begin{array}{l}42.7 * * * \\
(12.0)\end{array}$ & $\begin{array}{l}79.6 * * * \\
(16.2)\end{array}$ & $\begin{array}{l}-22.8 \\
(15.2)\end{array}$ & $\begin{array}{c}-8.8 \\
(19.0)\end{array}$ & $\begin{array}{c}-9.8 \\
(15.4)\end{array}$ & $\begin{array}{l}-11.4 \\
(25.5)\end{array}$ & $\begin{array}{l}177.6 \\
(32.1)\end{array}$ & $\begin{array}{l}111.7 \text { ** } \\
(55.2)\end{array}$ & $\begin{array}{l}102.4 * * * \\
(26.0)\end{array}$ & $\begin{array}{l}124.6 * * \\
(50.5)\end{array}$ \\
\hline Winter & $\begin{array}{c}-17.1 \text { *k* } \\
(6.3)\end{array}$ & $\begin{array}{l}-8.9 \\
(7.2)\end{array}$ & $\begin{array}{l}-5.8 \\
(7.1)\end{array}$ & $\begin{array}{c}-6.4 \\
(10.1)\end{array}$ & $\begin{array}{l}23.5 \text { ** } \\
(10.4)\end{array}$ & $\begin{array}{c}0.7 \\
(13.3)\end{array}$ & $\begin{array}{l}29.9 \text { *** } \\
(11.1)\end{array}$ & $\begin{array}{l}33.6 * \\
(17.4)\end{array}$ & $\begin{array}{l}-26.0 \\
(21.1)\end{array}$ & $\begin{array}{c}9.2 \\
(33.5)\end{array}$ & $\begin{array}{l}-20.0 \\
(18.4)\end{array}$ & $\begin{array}{c}-4.5 \\
(33.3)\end{array}$ \\
\hline Spring & $\begin{array}{l}-9.8 \\
(6.6)\end{array}$ & $\begin{array}{c}0.3 \\
(7.3)\end{array}$ & $\begin{array}{c}-31.8 * * * \\
(8.2)\end{array}$ & $\begin{array}{r}3.4 \\
(10.6)\end{array}$ & $\begin{array}{l}26.0 * * \\
(11.0)\end{array}$ & $\begin{array}{l}-13.6 \\
(13.7)\end{array}$ & $\begin{array}{r}5.0 \\
(12.2)\end{array}$ & $\begin{array}{c}13.0 \\
(18.3)\end{array}$ & $\begin{array}{l}-24.8 \\
(22.3)\end{array}$ & $\begin{array}{c}11.3 \\
(34.5)\end{array}$ & $\begin{array}{l}43.7 \text { ** } \\
(20.6)\end{array}$ & $\begin{array}{c}44.3 \\
(33.4)\end{array}$ \\
\hline Summer & $\begin{array}{l}-45.8 \text { *1k } \\
(6.4)\end{array}$ & $\begin{array}{c}-13.2 * \\
(7.4)\end{array}$ & $\begin{array}{l}-35.0 * * * \\
(7.9)\end{array}$ & $\begin{array}{c}-9.0 \\
(10.4)\end{array}$ & $\begin{array}{l}56.3 \text { **k* } \\
(10.0)\end{array}$ & $\begin{array}{c}13.2 \\
(13.7)\end{array}$ & $\begin{array}{l}26.4 * * \\
(11.5)\end{array}$ & $\begin{array}{c}20.1 \\
(17.7)\end{array}$ & $\begin{array}{l}-39.6 * \\
(21.1)\end{array}$ & $\begin{array}{l}-45.7 \\
(34.9)\end{array}$ & $\begin{array}{c}13.6 \\
(19.6)\end{array}$ & $\begin{array}{c}-8.6 \\
(33.2)\end{array}$ \\
\hline$\lambda$ & $\begin{array}{l}44.4 \text { *kok } \\
(5.6)\end{array}$ & $\begin{array}{l}58.0 * * \\
(6.5)\end{array}$ & $\begin{array}{l}40.8 * * * \\
(7.0)\end{array}$ & $\begin{array}{l}63.0 * * * \\
(12.9)\end{array}$ & $\begin{array}{c}110.9 \text { *⿻丷木 } \\
(9.9)\end{array}$ & $\begin{array}{l}249.7 \text { *k* } \\
(14.6)\end{array}$ & $\begin{array}{l}116.2 \\
(11.2)\end{array}$ & $\begin{array}{l}238.4 * * * \\
(22.9)\end{array}$ & $\begin{array}{l}104.9 * \\
(16.6)\end{array}$ & $\begin{array}{c}29.0 \\
(22.7)\end{array}$ & $\begin{array}{l}136.3 \text { **⿰㇇⿰亅⿱丿丶丶 } \\
(14.0)\end{array}$ & $\begin{array}{l}101.3 * * * \\
(36.2)\end{array}$ \\
\hline
\end{tabular}

Notes: Table reports selected coefficients and asymptotic standard errors (in parentheses) from correlated Tobit models of time use estimated using data fromthe ATUS. As described in the text, the models are estimated jointly with discrete-choice models of family structure. Estimates for the remaining time use coefficients and for the family structure models are reported in Appendix B.

* Significant at .10 level. ** Significant at .05 level. *** Significant at .01 level. 
Table 3. Selected Coefficient Estimates from Correlated Tobit Models of Time-Use: UKTUS Sample

\begin{tabular}{|c|c|c|c|c|c|c|c|c|c|c|c|c|}
\hline & \multicolumn{4}{|c|}{ Daily Minutes of Primary Child Care } & \multicolumn{4}{|c|}{ Daily Minutes of Passive Child Care } & \multicolumn{4}{|c|}{ Daily Minutes of Market Work } \\
\hline & \multicolumn{2}{|c|}{ Women } & \multicolumn{2}{|c|}{ Men } & \multicolumn{2}{|c|}{ Women } & \multicolumn{2}{|c|}{ Men } & \multicolumn{2}{|c|}{ Women } & \multicolumn{2}{|c|}{ Men } \\
\hline & Weekday & Weekend & Weekday & Weekend & Weekday & Weekend & Weekday & Weekend & Weekday & Weekend & Weekday & Weekend \\
\hline Cohabiting & $\begin{array}{l}-20.1 \\
(13.4)\end{array}$ & $\begin{array}{c}0.7 \\
(15.2)\end{array}$ & $\begin{array}{l}-57.1^{*} \\
(29.3)\end{array}$ & $\begin{array}{c}17.4 \\
(42.2)\end{array}$ & $\begin{array}{l}-47.1 \\
(29.1)\end{array}$ & $\begin{array}{l}-43.5 \\
(41.4)\end{array}$ & $\begin{array}{c}-160.3^{* * *} \\
(61.1)\end{array}$ & $\begin{array}{c}-113.3 \\
(89.3)\end{array}$ & $\begin{array}{l}111.5^{* *} \\
(49.0)\end{array}$ & $\begin{array}{c}45.3 \\
(96.1)\end{array}$ & $\begin{array}{l}190.8^{* *} \\
(89.0)\end{array}$ & $\begin{array}{c}44.2 \\
(193.3)\end{array}$ \\
\hline Married & $\begin{array}{c}-17.3 * \\
(8.9)\end{array}$ & $\begin{array}{l}-15.3 \\
(10.5)\end{array}$ & $\begin{array}{l}-41.5 \\
(27.3)\end{array}$ & $\begin{array}{c}19.2 \\
(41.0)\end{array}$ & $\begin{array}{l}-67.9 * * * \\
(19.3)\end{array}$ & $\begin{array}{l}-73.7 * * \\
(30.8)\end{array}$ & $\begin{array}{c}-162.6^{* * *} \\
(57.8)\end{array}$ & $\begin{array}{c}-105.0 \\
(84.4)\end{array}$ & $\begin{array}{l}90.2^{* * *} \\
(32.1)\end{array}$ & $\begin{array}{l}116.3 * \\
(65.7)\end{array}$ & $\begin{array}{l}226.0 * * * \\
(81.9)\end{array}$ & $\begin{array}{c}-1.6 \\
(181.2)\end{array}$ \\
\hline Children 0-3 & $\begin{array}{l}85.4 * * * \\
(7.7)\end{array}$ & $\begin{array}{l}82.2 * * * \\
(8.6)\end{array}$ & $\begin{array}{l}45.0^{* * * *} \\
(8.0)\end{array}$ & $\begin{array}{l}49.7 * * * \\
(9.7)\end{array}$ & $\begin{array}{l}91.4 \\
(16.5)\end{array}$ & $\begin{array}{l}-12.1 \\
(27.3)\end{array}$ & $\begin{array}{c}24.3 \\
(17.5)\end{array}$ & $\begin{array}{l}-40.7 \\
(30.0)\end{array}$ & $\begin{array}{c}-206.6^{* * *} \\
(34.7)\end{array}$ & $\begin{array}{c}-173.7 * * * \\
(66.4)\end{array}$ & $\begin{array}{l}-60.5 * * \\
(30.2)\end{array}$ & $\begin{array}{c}-1.6 \\
(68.4)\end{array}$ \\
\hline Children 4-6 & $\begin{array}{l}36.7 * * * \\
(7.7)\end{array}$ & $\begin{array}{l}18.3 \text { ** } \\
(8.8)\end{array}$ & $\begin{array}{l}26.3^{* * *} \\
(8.7)\end{array}$ & $\begin{array}{l}13.0 \\
(9.3)\end{array}$ & $\begin{array}{c}8.4 \\
(15.3)\end{array}$ & $\begin{array}{c}-2.5 \\
(25.5)\end{array}$ & $\begin{array}{c}14.4 \\
(17.6)\end{array}$ & $\begin{array}{c}4.6 \\
(28.5)\end{array}$ & $\begin{array}{l}-89.6 \text { *** } \\
(29.9)\end{array}$ & $\begin{array}{l}-48.7 \\
(62.7)\end{array}$ & $\begin{array}{l}-35.4 \\
(30.0)\end{array}$ & $\begin{array}{c}58.4 \\
(62.0)\end{array}$ \\
\hline Children 7-11 & $\begin{array}{l}7.7 \\
(6.1)\end{array}$ & $\begin{array}{l}-3.3 \\
(6.5)\end{array}$ & $\begin{array}{l}9.7 \\
(6.1)\end{array}$ & $\begin{array}{l}-4.7 \\
(7.0)\end{array}$ & $\begin{array}{l}41.2^{* * * *} \\
(10.9)^{2}\end{array}$ & $\begin{array}{c}4.5 \\
(17.5)\end{array}$ & $\begin{array}{l}25.2^{* *} \\
(12.7)\end{array}$ & $\begin{array}{c}21.3 \\
(19.4)\end{array}$ & $\begin{array}{l}-65.5 * * * \\
(21.5)\end{array}$ & $\begin{array}{l}-18.9 \\
(41.1)\end{array}$ & $\begin{array}{l}-44.0 * * \\
(21.3)\end{array}$ & $\begin{array}{l}-42.8 \\
(52.7)\end{array}$ \\
\hline Children 12-17 & $\begin{array}{c}-14.6^{* *} \\
(6.3)\end{array}$ & $\begin{array}{c}-19.6 * * * \\
(6.3)\end{array}$ & $\begin{array}{l}-5.7 \\
(6.5)\end{array}$ & $\begin{array}{c}-25.2 * * * \\
(8.0)\end{array}$ & $\begin{array}{c}11.4 \\
(11.1)\end{array}$ & $\begin{array}{l}-10.8 \\
(16.9)\end{array}$ & $\begin{array}{c}5.3 \\
(12.6)\end{array}$ & $\begin{array}{l}-23.6 \\
(19.8)\end{array}$ & $\begin{array}{l}-22.0 \\
(21.2)\end{array}$ & $\begin{array}{c}12.0 \\
(39.5)\end{array}$ & $\begin{array}{l}-61.1^{* * *} \\
(21.4)\end{array}$ & $\begin{array}{c}48.7 \\
(49.2)\end{array}$ \\
\hline Other Adults & $\begin{array}{l}-4.9 \\
(8.8)\end{array}$ & $\begin{array}{l}-18.5 * \\
(10.5)\end{array}$ & $\begin{array}{l}-11.8 \\
(12.7)\end{array}$ & $\begin{array}{c}-2.1 \\
(13.2)\end{array}$ & $\begin{array}{l}-32.4 \\
(19.7)\end{array}$ & $\begin{array}{l}-89.5 * * * \\
(25.3)\end{array}$ & $\begin{array}{l}-12.7 \\
(24.6)\end{array}$ & $\begin{array}{l}-64.0 * * \\
(32.3)\end{array}$ & $\begin{array}{l}-39.8 \\
(31.2)\end{array}$ & $\begin{array}{l}-53.2 \\
(59.1)\end{array}$ & $\begin{array}{c}-0.1 \\
(33.7)\end{array}$ & $\begin{array}{l}-20.8 \\
(62.4)\end{array}$ \\
\hline $\begin{array}{l}\text { First or Post-Grad } \\
\text { Degree }\end{array}$ & $\begin{array}{c}3.2 \\
(12.0)\end{array}$ & $\begin{array}{l}26.4^{* *} \\
(13.0)\end{array}$ & $\begin{array}{r}1.8 \\
(13.7)\end{array}$ & $\begin{array}{c}21.7 \\
(15.8)\end{array}$ & $\begin{array}{l}-35.5 \\
(24.6)\end{array}$ & $\begin{array}{c}24.2 \\
(35.5)\end{array}$ & $\begin{array}{l}-28.5 \\
(26.2)\end{array}$ & $\begin{array}{c}52.7 \\
(39.4)\end{array}$ & $\begin{array}{l}161.6^{* * *} \\
(47.7)\end{array}$ & $\begin{array}{l}55.7 \\
(85.7)\end{array}$ & $\begin{array}{c}19.4 \\
(46.5)\end{array}$ & $\begin{array}{l}-153.7 \\
(101.8)\end{array}$ \\
\hline $\begin{array}{l}\text { Other Higher Educ. } \\
\text { Degree }\end{array}$ & $\begin{array}{c}-5.0 \\
(28.2)\end{array}$ & $\begin{array}{c}14.8 \\
(28.1)\end{array}$ & $\begin{array}{l}-24.2 \\
(21.3)\end{array}$ & $\begin{array}{c}-3.4 \\
(22.2)\end{array}$ & $\begin{array}{l}-42.6 \\
(56.1)\end{array}$ & $\begin{array}{l}-32.3 \\
(99.0)\end{array}$ & $\begin{array}{l}-61.2 \\
(39.1)\end{array}$ & $\begin{array}{l}-16.2 \\
(48.4)\end{array}$ & $\begin{array}{l}175.4 * \\
(101.2)\end{array}$ & $\begin{array}{l}-240.5 \\
(280.9)\end{array}$ & $\begin{array}{c}67.3 \\
(68.1)\end{array}$ & $\begin{array}{l}-231.5 * \\
(136.8)\end{array}$ \\
\hline $\begin{array}{l}\text { Higher Educ. Below } \\
\text { Degree Level }\end{array}$ & $\begin{array}{c}-0.8 \\
(11.4)\end{array}$ & $\begin{array}{c}0.1 \\
(12.5)\end{array}$ & $\begin{array}{r}2.0 \\
(14.7)\end{array}$ & $\begin{array}{c}23.0 \\
(15.8)\end{array}$ & $\begin{array}{l}-18.8 \\
(21.9)\end{array}$ & $\begin{array}{c}-4.0 \\
(33.1)\end{array}$ & $\begin{array}{c}5.2 \\
(28.0)\end{array}$ & $\begin{array}{l}73.0 * \\
(40.8)\end{array}$ & $\begin{array}{l}125.3 \\
(38.9)\end{array}$ & $\begin{array}{c}55.9 \\
(74.2)\end{array}$ & $\begin{array}{c}43.2 \\
(52.5)\end{array}$ & $\begin{array}{l}-269.2 * * \\
(105.0)\end{array}$ \\
\hline "A" level or voc. level & $\begin{array}{l}-12.8 \\
(12.4)\end{array}$ & $\begin{array}{c}10.2 \\
(12.8)\end{array}$ & $\begin{array}{r}9.5 \\
(12.6)\end{array}$ & $\begin{array}{c}3.7 \\
(13.6)\end{array}$ & $\begin{array}{l}-53.6 * * \\
(23.5)\end{array}$ & $\begin{array}{c}12.9 \\
(38.5)\end{array}$ & $\begin{array}{c}-0.1 \\
(24.0)\end{array}$ & $\begin{array}{c}19.8 \\
(38.2)\end{array}$ & $\begin{array}{l}152.4 \\
(46.6)\end{array}$ & $\begin{array}{c}-4.9 \\
(87.1)\end{array}$ & $\begin{array}{c}31.8 \\
(39.9)\end{array}$ & $\begin{array}{c}22.0 \\
(87.1)\end{array}$ \\
\hline "O" level, gcse grade i & $\begin{array}{c}-10.5 \\
(9.7)\end{array}$ & $\begin{array}{l}-14.1 \\
(10.3)\end{array}$ & $\begin{array}{c}11.7 \\
(12.7)\end{array}$ & $\begin{array}{c}-7.2 \\
(14.6)\end{array}$ & $\begin{array}{r}0.8 \\
(19.2)\end{array}$ & $\begin{array}{c}42.2 \\
(27.6)\end{array}$ & $\begin{array}{c}22.5 \\
(22.6)\end{array}$ & $\begin{array}{l}60.7 * \\
(36.8)\end{array}$ & $\begin{array}{l}101.6^{* * *} \\
(35.1)\end{array}$ & $\begin{array}{l}-43.5 \\
(64.9)\end{array}$ & $\begin{array}{c}9.6 \\
(40.9)\end{array}$ & $\begin{array}{l}-98.5 \\
(85.4)\end{array}$ \\
\hline gcse below grade c & $\begin{array}{l}-21.0 \\
(18.1)\end{array}$ & $\begin{array}{l}-22.1 \\
(18.1)\end{array}$ & $\begin{array}{r}7.6 \\
(23.7)\end{array}$ & $\begin{array}{c}-5.7 \\
(22.8)\end{array}$ & $\begin{array}{c}-4.5 \\
(31.8)\end{array}$ & $\begin{array}{r}8.6 \\
(47.2)\end{array}$ & $\begin{array}{c}27.3 \\
(43.8)\end{array}$ & $\begin{array}{c}41.7 \\
(65.6)\end{array}$ & $\begin{array}{l}102.8 * \\
(58.9)\end{array}$ & $\begin{array}{l}-151.6 \\
(122.5)\end{array}$ & $\begin{array}{c}16.9 \\
(67.8)\end{array}$ & $\begin{array}{l}192.5 \\
(133.4)\end{array}$ \\
\hline $\begin{array}{l}\text { Other Known } \\
\text { Qualifications }\end{array}$ & $\begin{array}{l}-10.4 \\
(21.6)\end{array}$ & $\begin{array}{l}-14.9 \\
(21.5)\end{array}$ & $\begin{array}{c}-9.1 \\
(17.7)\end{array}$ & $\begin{array}{c}-3.0 \\
(17.7)\end{array}$ & $\begin{array}{c}54.0 \\
(37.7)\end{array}$ & $\begin{array}{l}-25.4 \\
(48.9)\end{array}$ & $\begin{array}{l}-54.7 * \\
(32.4)\end{array}$ & $\begin{array}{l}-74.4 \\
(49.3)\end{array}$ & $\begin{array}{l}-92.8 \\
(73.2)\end{array}$ & $\begin{array}{l}-119.7 \\
(138.4)\end{array}$ & $\begin{array}{l}106.1 \text { ** } \\
(54.1)\end{array}$ & $\begin{array}{c}-13.0 \\
(104.6)\end{array}$ \\
\hline Winter & $\begin{array}{l}11.8 \\
(9.5)\end{array}$ & $\begin{array}{c}12.5 \\
(10.4)\end{array}$ & $\begin{array}{l}-17.0 \\
(11.9)\end{array}$ & $\begin{array}{c}1.1 \\
(13.2)\end{array}$ & $\begin{array}{c}7.2 \\
(19.9)\end{array}$ & $\begin{array}{c}16.4 \\
(29.1)\end{array}$ & $\begin{array}{c}0.7 \\
(24.6)\end{array}$ & $\begin{array}{l}-28.1 \\
(36.7)\end{array}$ & $\begin{array}{l}-18.2 \\
(35.4)\end{array}$ & $\begin{array}{c}66.7 \\
(70.8)\end{array}$ & $\begin{array}{c}49.2 \\
(41.6)\end{array}$ & $\begin{array}{c}45.8 \\
(82.4)\end{array}$ \\
\hline Spring & $\begin{array}{l}-5.3 \\
(9.5)\end{array}$ & $\begin{array}{r}2.8 \\
(10.7)\end{array}$ & $\begin{array}{l}-14.4 \\
(10.9)\end{array}$ & $\begin{array}{c}-5.8 \\
(12.0)\end{array}$ & $\begin{array}{c}20.8 \\
(19.8)\end{array}$ & $\begin{array}{c}17.9 \\
(28.2)\end{array}$ & $\begin{array}{c}-4.2 \\
(22.0)\end{array}$ & $\begin{array}{c}-7.0 \\
(31.9)\end{array}$ & $\begin{array}{l}-11.4 \\
(33.0)\end{array}$ & $\begin{array}{c}12.0 \\
(62.9)\end{array}$ & $\begin{array}{l}-18.7 \\
(36.0)\end{array}$ & $\begin{array}{c}-6.2 \\
(75.4)\end{array}$ \\
\hline Summer & $\begin{array}{l}-28.3^{* * * *} \\
(9.9)\end{array}$ & $\begin{array}{c}1.5 \\
(10.6)\end{array}$ & $\begin{array}{l}-15.3 \\
(10.8)\end{array}$ & $\begin{array}{l}-10.7 \\
(12.8)\end{array}$ & $\begin{array}{l}73.9^{* * * *} \\
(18.5)^{4}\end{array}$ & $\begin{array}{l}25.3 \\
(28.1)\end{array}$ & $\begin{array}{l}22.6 \\
(21.4)\end{array}$ & $\begin{array}{l}-32.0 \\
(33.8)\end{array}$ & $\begin{array}{l}-80.0 * * \\
(35.0)\end{array}$ & $\begin{array}{l}-38.9 \\
(66.7)\end{array}$ & $\begin{array}{l}-54.0 \\
(36.0)\end{array}$ & $\begin{array}{c}32.3 \\
(76.0)\end{array}$ \\
\hline$\lambda$ & $\begin{array}{l}43.7 * * * \\
(8.4)\end{array}$ & $\begin{array}{l}65.4^{* * *} \\
(11.9)\end{array}$ & $\begin{array}{l}21.1 * * * \\
(6.7)\end{array}$ & $\begin{array}{l}42.4 * * * \\
(12.4)\end{array}$ & $\begin{array}{l}306.8 * * * \\
(42.8)\end{array}$ & $\begin{array}{l}569.9 * * * \\
(80.3)\end{array}$ & $\begin{array}{l}206.4 \text { *** } \\
(34.2)\end{array}$ & $\begin{array}{l}504.3 * * * \\
(76.0)\end{array}$ & $\begin{array}{c}-5.0 \\
(13.1)\end{array}$ & $\begin{array}{l}-18.2 \\
(22.9)\end{array}$ & $\begin{array}{c}10.4 \\
(13.7)\end{array}$ & $\begin{array}{c}-0.9 \\
(29.3)\end{array}$ \\
\hline
\end{tabular}

Notes: Table reports selected coefficients and asymptotic standard errors (in parentheses) from correlated Tobit models of time use estimated using data from the UKTUS. As described in the text, the models are estimated jointly with discrete-choice models of family structure. Estimates for the remaining time use coefficients and for the family structure models are reported in Appendix C.

* Significant at .10 level. ** Significant at .05 level. *** Significant at .01 level. 


\section{Table 4}

\section{Marginal Effects of Living Arrangements}

\section{Panel A: ATUS}

\begin{tabular}{|c|c|c|c|c|c|c|c|c|c|c|c|c|}
\hline & \multicolumn{4}{|c|}{ Primary Care } & \multicolumn{4}{|c|}{ Passive Care } & \multicolumn{4}{|c|}{ Market Work } \\
\hline & \multicolumn{2}{|c|}{ Women } & \multicolumn{2}{|c|}{ Men } & \multicolumn{2}{|c|}{ Women } & \multicolumn{2}{|c|}{ Men } & \multicolumn{2}{|c|}{ Women } & \multicolumn{2}{|c|}{ Men } \\
\hline & Weekday & Weekend & Weekday & Weekend & Weekday & Weekend & Weekday & Weekend & Weekday & Weekend & Weekday & Weekend \\
\hline $\begin{array}{l}\text { Marginals } \\
\text { Cohabiting }\end{array}$ & -12.6 & 5.4 & -52.0 & -3.6 & 0.2 & -44.4 & -20.4 & -23.1 & -67.4 & -21.5 & -42.1 & 22.4 \\
\hline Married & -11.3 & -13.1 & -36.1 & -16.8 & -10.3 & -51.6 & -42.0 & -24.2 & -80.8 & -19.7 & 8.4 & 8.0 \\
\hline + Child 0-3 & 73.3 & 58.5 & 18.8 & 36.3 & 54.5 & 0.6 & 5.0 & 15.6 & -82.3 & -14.2 & -24.6 & -14.9 \\
\hline + Child 4-6 & 34.6 & 21.2 & 14.3 & 16.9 & 30.0 & -3.7 & 7.4 & 3.6 & -57.0 & -1.0 & -3.1 & 3.3 \\
\hline + Child 7-11 & 17.8 & 1.4 & 4.7 & 5.6 & 34.5 & 16.9 & 10.1 & 31.1 & -47.4 & -4.9 & -24.5 & -6.8 \\
\hline + Child 12-17 & 1.2 & -7.2 & -1.4 & -7.1 & 12.5 & -2.1 & -2.3 & 3.0 & -19.5 & 4.6 & 6.6 & -4.3 \\
\hline + Other adult & -14.2 & -0.2 & -2.0 & -11.3 & -14.2 & -23.9 & -7.7 & -24.3 & 17.7 & 6.2 & -0.9 & 3.4 \\
\hline
\end{tabular}

Panel B: UKTUS

\begin{tabular}{|c|c|c|c|c|c|c|c|c|c|c|c|c|}
\hline & \multicolumn{4}{|c|}{ Primary Care } & \multicolumn{4}{|c|}{ Passive Care } & \multicolumn{4}{|c|}{ Market Work } \\
\hline & \multicolumn{2}{|c|}{ Women } & \multicolumn{2}{|c|}{ Men } & \multicolumn{2}{|c|}{ Women } & \multicolumn{2}{|c|}{ Men } & \multicolumn{2}{|c|}{ Women } & \multicolumn{2}{|c|}{ Men } \\
\hline & Weekday & Weekend & Weekday & Weekend & Weekday & Weekend & Weekday & Weekend & Weekday & Weekend & Weekday & Weekend \\
\hline $\begin{array}{l}\text { Marginals } \\
\text { Cohabiting }\end{array}$ & -12.6 & 0.4 & -26.2 & 5.8 & -28.1 & -24.7 & -90.4 & -61.6 & 59.4 & 7.0 & 146.0 & 13.2 \\
\hline Married & -10.9 & -7.3 & -20.2 & 6.4 & -40.0 & -41.3 & -91.5 & -57.3 & 47.0 & 19.8 & 176.1 & -0.5 \\
\hline + Child 0-3 & 61.0 & 45.8 & 22.1 & 21.3 & 55.3 & -6.7 & 12.3 & -20.8 & -92.3 & -25.4 & -50.6 & -0.5 \\
\hline + Child 4-6 & 24.2 & 9.0 & 12.0 & 4.9 & 4.9 & -1.3 & 7.2 & 2.4 & -45.3 & -8.4 & -29.9 & 17.8 \\
\hline + Child 7-11 & 4.8 & -1.5 & 4.1 & -1.7 & 24.3 & 2.5 & 12.7 & 11.2 & -34.0 & -3.4 & -37.1 & -11.9 \\
\hline + Child 12-17 & -8.8 & -8.8 & -2.3 & -8.2 & 6.7 & -6.0 & 2.7 & -12.2 & -11.9 & 2.2 & -51.1 & 14.7 \\
\hline + Other adult & -3.0 & -8.3 & -4.6 & -0.7 & -18.4 & -47.8 & -6.1 & -32.3 & -21.2 & -9.1 & 0.0 & -5.9 \\
\hline
\end{tabular}




\section{Appendix A: Sample Statistics}

Table A1

\author{
ATUS Sample Means \\ By Gender and Sample
}

Cohabiting

Married

Children 0-3

Children 4-6

Children 7-11

Children 12-17

Other adults

Age

Less than high school (Base Case)

High school graduate

Bachelor's degree or more

Unemployment rate

Non-metro area

African American

Hispanic

Northeast (Base Case)

Midwest

South

West

Fall (Base Case)

Winter

Spring

Summer

2004 Sample

Number of Observations
Women

Full $\underline{\text { Time }}$

Sample Sample

$0.036 \quad 0.031$

$0.592 \quad 0.709$

$0.219 \quad 0.393$

$0.181 \quad 0.326$

$0.329 \quad 0.592$

$0.312 \quad 0.560$

$0.269 \quad 0.173$

$40.743 \quad 37.401$

$0.088 \quad 0.087$

$0.569 \quad 0.573$

0.343

5.793

0.191

0.124

0.098

0.192

0.259

0.345

0.204

0.244

0.264

0.239

0.253

0.398

0.339

5.795

0.193

0.108

0.113

0.194

0.263

0.340

0.203

0.245

0.269

0.234

0.252

0.392

11427

6359
Men

Time Full Use

Sample Sample

$0.033 \quad 0.028$

$0.651 \quad 0.895$

$0.201 \quad 0.416$

$0.169 \quad 0.350$

$0.281 \quad 0.583$

$0.266 \quad 0.553$

$0.312 \quad 0.160$

$41.557 \quad 39.845$

$0.101 \quad 0.086$

$0.553 \quad 0.529$

$0.346 \quad 0.385$

$5.778 \quad 5.789$

$0.195 \quad 0.200$

$0.097 \quad 0.072$

$0.098 \quad 0.106$

$0.193 \quad 0.200$

$0.255 \quad 0.258$

$0.341 \quad 0.326$

$0.211 \quad 0.216$

$0.252 \quad 0.249$

$0.269 \quad 0.275$

$0.233 \quad 0.235$

$0.246 \quad 0.242$

$0.400 \quad 0.403$

9596

4620 


\section{Table A2}

\section{UKTUS Sample Means}

By Gender and Sample

\begin{tabular}{|c|c|c|c|c|}
\hline & Wo & nen & & \\
\hline & & $\underline{\text { Time }}$ & & $\underline{\text { Time }}$ \\
\hline & $\underline{\text { Full }}$ & $\overline{\text { Use }}$ & Full & $\overline{\text { Use }}$ \\
\hline & Sample & Sample & Sample & Sample \\
\hline Cohabiting & 0.110 & 0.106 & 0.115 & 0.132 \\
\hline Married & 0.586 & 0.684 & 0.609 & 0.841 \\
\hline Children 0-3 & 0.185 & 0.361 & 0.153 & 0.368 \\
\hline Children 4-6 & 0.137 & 0.274 & 0.108 & 0.262 \\
\hline Children 7-11 & 0.282 & 0.590 & 0.226 & 0.566 \\
\hline Children 12-17 & 0.303 & 0.628 & 0.261 & 0.640 \\
\hline Other adults & 0.450 & 0.177 & 0.498 & 0.168 \\
\hline Age & 38.654 & 36.911 & 40.647 & 39.843 \\
\hline No qualifications (Base Case) & 0.332 & 0.310 & 0.324 & 0.307 \\
\hline Other known qualification & 0.053 & 0.042 & 0.091 & 0.072 \\
\hline gcse below grade c & 0.040 & 0.056 & 0.035 & 0.042 \\
\hline "O" level, gcse grade a-c & 0.199 & 0.230 & 0.143 & 0.160 \\
\hline "A" level or voc. level 3 & 0.103 & 0.097 & 0.141 & 0.154 \\
\hline Other higher educ. degree & 0.158 & 0.156 & 0.142 & 0.150 \\
\hline First or post-grad. degree & 0.116 & 0.110 & 0.125 & 0.116 \\
\hline Unemployment rate & 6.883 & 6.821 & 6.756 & 6.587 \\
\hline Rural & 0.429 & 0.424 & 0.447 & 0.453 \\
\hline London & 0.085 & 0.081 & 0.081 & 0.072 \\
\hline Fall (Base Case) & & 0.294 & & 0.276 \\
\hline Winter & & 0.218 & & 0.207 \\
\hline Spring & & 0.257 & & 0.269 \\
\hline Summer & & 0.232 & & 0.248 \\
\hline Number of Observations & 3574 & 1511 & 3274 & 1131 \\
\hline
\end{tabular}




\section{Appendix B. Remaining Coefficient Estimates from Correlated Tobit Models of Time-Use: ATUS Sample}

Table B1

Time Use Equations

\begin{tabular}{|c|c|c|c|c|c|c|c|c|c|c|c|c|c|}
\hline & \multicolumn{5}{|c|}{ Daily Minutes of Primary Child Care } & \multicolumn{4}{|c|}{ Daily Minutes of Passive Child Care } & \multicolumn{4}{|c|}{ Daily Minutes of Market Work } \\
\hline & \multicolumn{3}{|c|}{ Women } & \multicolumn{2}{|c|}{ Men } & \multicolumn{2}{|c|}{ Women } & \multicolumn{2}{|c|}{ Men } & \multicolumn{2}{|c|}{ Women } & \multicolumn{2}{|c|}{ Men } \\
\hline & Weekd & & Weekend & Weekday & Weekend & Weekday & Weekend & Weekday & Weekend & Weekday & Weekend & Weekday & Weekend \\
\hline Intercept & $\begin{array}{l}-99.5 \\
(51.1)\end{array}$ & $*$ & $\begin{array}{c}-276.4^{* * *} \\
(54.3)\end{array}$ & $\begin{array}{c}-196.1^{* * *} \\
(69.2)\end{array}$ & $\begin{array}{c}-402.6{ }^{* * *} \\
(89.8)\end{array}$ & $\begin{array}{c}81.5 \\
(78.5)\end{array}$ & $\begin{array}{c}-203.3 * * \\
(99.1)\end{array}$ & $\begin{array}{l}111.6 \\
(93.2)\end{array}$ & $\begin{array}{l}-538.22^{* * *} \\
(141.6)\end{array}$ & $\begin{array}{l}-519.8^{* * * *} \\
(169.1)\end{array}$ & $\begin{array}{l}-858.7^{* * *} \\
(276.8)\end{array}$ & $\begin{array}{c}-47.7 \\
(160.1)\end{array}$ & $\begin{array}{l}-610.5 \text { ** } \\
(282.8)\end{array}$ \\
\hline Age & $\begin{array}{c}7.6 \\
(2.5)\end{array}$ & $* * *$ & $\begin{array}{l}13.8 \text { *** } \\
(2.8)\end{array}$ & $\begin{array}{l}11.3 \text { *** } \\
(3.3)\end{array}$ & $\begin{array}{l}18.5 \text { *** } \\
(4.3)\end{array}$ & $\begin{array}{l}-1.6 \\
(3.9)\end{array}$ & $\begin{array}{l}25.6 * * * \\
(4.9)\end{array}$ & $\begin{array}{l}-4.7 \\
(4.4)\end{array}$ & $\begin{array}{l}38.6 \text { *** } \\
(6.5)\end{array}$ & $\begin{array}{l}43.4^{* * *} \\
(8.4)\end{array}$ & $\begin{array}{c}18.7 \\
(13.9)\end{array}$ & $\begin{array}{l}19.2 \text { ** } \\
(7.7)\end{array}$ & $\begin{array}{c}7.9 \\
(12.9)\end{array}$ \\
\hline Age Squared & $\begin{array}{r}-10.4 \\
(3.3)\end{array}$ & $* * *$ & $\begin{array}{l}-18.4 * * * \\
(3.7)\end{array}$ & $\begin{array}{c}-14.5{ }^{* * *} \\
(4.1)\end{array}$ & $\begin{array}{l}-23.9 * * * \\
(5.3)\end{array}$ & $\begin{array}{l}-2.6 \\
(5.1)\end{array}$ & $\begin{array}{l}-42.3 * * * \\
(6.4)\end{array}$ & $\begin{array}{c}2.6 \\
(5.5)\end{array}$ & $\begin{array}{l}-55.9 * * * \\
(8.0)\end{array}$ & $\begin{array}{l}-57.5 * * * \\
(10.9)\end{array}$ & $\begin{array}{l}-25.7 \\
(18.1)\end{array}$ & $\begin{array}{c}-24.3 * * \\
(9.5)\end{array}$ & $\begin{array}{c}-8.8 \\
(15.8)\end{array}$ \\
\hline African American & $\begin{array}{r}-38.3 \\
(8.4)\end{array}$ & $* * *$ & $\begin{array}{l}-40.8 * * * \\
(8.7)\end{array}$ & $\begin{array}{c}-7.3 \\
(10.9)\end{array}$ & $\begin{array}{l}-45.1 * * * \\
(15.2)\end{array}$ & $\begin{array}{l}-24.1 * \\
(12.3)\end{array}$ & $\begin{array}{l}-48.5 * * * \\
(15.3)\end{array}$ & $\begin{array}{l}-20.5 \\
(16.4)\end{array}$ & $\begin{array}{l}-54.9 * * \\
(23.2)\end{array}$ & $\begin{array}{l}-26.4 \\
(27.0)\end{array}$ & $\begin{array}{l}-23.3 \\
(39.8)\end{array}$ & $\begin{array}{l}-96.1 \\
(25.6)\end{array}$ & $\begin{array}{c}-142.7 \\
(46.7)\end{array}$ \\
\hline Hispanic & $\begin{array}{c}-17.3 \\
(7.7)\end{array}$ & $* *$ & $\begin{array}{c}-10.2 \\
(8.5)\end{array}$ & $\begin{array}{l}-14.7 \\
(10.0)\end{array}$ & $\begin{array}{l}-26.44^{* *} \\
(13.1)\end{array}$ & $\begin{array}{l}27.44^{* *} \\
(12.4)\end{array}$ & $\begin{array}{c}23.2 \\
(16.8)\end{array}$ & $\begin{array}{c}15.8 \\
(14.1)\end{array}$ & $\begin{array}{c}-6.1 \\
(22.1)\end{array}$ & $\begin{array}{c}-8.0 \\
(25.8)\end{array}$ & $\begin{array}{c}-2.2 \\
(44.4)\end{array}$ & $\begin{array}{l}-24.9 \\
(23.9)\end{array}$ & $\begin{array}{c}66.4 \\
(41.2)\end{array}$ \\
\hline Mid West & $\begin{array}{r}-18.8 \\
(6.8)\end{array}$ & $* * *$ & $\begin{array}{l}-7.1 \\
(7.7)\end{array}$ & $\begin{array}{c}-10.7 \\
(8.4)\end{array}$ & $\begin{array}{c}-5.4 \\
(11.2)\end{array}$ & $\begin{array}{c}-6.1 \\
(11.0)\end{array}$ & $\begin{array}{c}-0.8 \\
(14.7)\end{array}$ & $\begin{array}{c}14.9 \\
(11.5)\end{array}$ & $\begin{array}{c}14.7 \\
(19.3)\end{array}$ & $\begin{array}{c}33.6 \\
(22.8)\end{array}$ & $\begin{array}{c}37.9 \\
(37.0)\end{array}$ & $\begin{array}{c}20.3 \\
(20.3)\end{array}$ & $\begin{array}{c}-3.6 \\
(36.3)\end{array}$ \\
\hline South & $\begin{array}{r}-13.3 \\
(6.2)\end{array}$ & $* *$ & $\begin{array}{c}-14.0 * \\
(7.4)\end{array}$ & $\begin{array}{c}-11.2 \\
(8.0)\end{array}$ & $\begin{array}{l}-13.4 \\
(10.5)\end{array}$ & $\begin{array}{c}-9.1 \\
(10.4)\end{array}$ & $\begin{array}{c}16.9 \\
(13.9)\end{array}$ & $\begin{array}{c}-3.8 \\
(11.8)\end{array}$ & $\begin{array}{c}-9.5 \\
(17.7)\end{array}$ & $\begin{array}{c}18.8 \\
(21.7)\end{array}$ & $\begin{array}{c}45.0 \\
(35.4)\end{array}$ & $\begin{array}{c}26.1 \\
(19.7)\end{array}$ & $\begin{array}{c}13.7 \\
(33.2)\end{array}$ \\
\hline West & $\begin{array}{r}-20.5 \\
(7.3)\end{array}$ & $* * *$ & $\begin{array}{r}-14.3 \\
(8.7)\end{array}$ & $\begin{array}{l}-7.9 \\
(8.8)\end{array}$ & $\begin{array}{l}-12.6 \\
(12.4)\end{array}$ & $\begin{array}{c}17.2 \\
(11.9)\end{array}$ & $\begin{array}{l}41.0 * * \\
(16.4)\end{array}$ & $\begin{array}{c}7.3 \\
(13.2)\end{array}$ & $\begin{array}{l}67.6 * * * \\
(20.2)\end{array}$ & $\begin{array}{c}-2.1 \\
(24.4)\end{array}$ & $\begin{array}{c}37.9 \\
(40.7)\end{array}$ & $\begin{array}{c}19.4 \\
(21.8)\end{array}$ & $\begin{array}{l}-75.4 * * \\
(38.3)\end{array}$ \\
\hline Non-Metro & $\begin{array}{r}-21.5 \\
(6.6)\end{array}$ & $* * *$ & $\begin{array}{l}-9.6 \\
(6.8)\end{array}$ & $\begin{array}{l}-6.0 \\
(7.3)\end{array}$ & $\begin{array}{c}-14.0 \\
(9.5)\end{array}$ & $\begin{array}{l}15.5 * \\
(9.2)\end{array}$ & $\begin{array}{l}36.0 \\
(12.1)\end{array}$ & $\begin{array}{l}17.1 * \\
(9.8)\end{array}$ & $\begin{array}{l}-16.6 \\
(16.0)\end{array}$ & $\begin{array}{l}40.3 * * \\
(20.1)\end{array}$ & $\begin{array}{c}44.6 \\
(30.1)\end{array}$ & $\begin{array}{l}21.7 \\
(17.3)\end{array}$ & $\begin{array}{l}87.5 \text { *** } \\
(29.2)\end{array}$ \\
\hline Unemployment Rate & $\begin{array}{c}1.5 \\
(2.8)\end{array}$ & & $\begin{array}{l}-2.3 \\
(3.0)\end{array}$ & $\begin{array}{l}-1.6 \\
(3.3)\end{array}$ & $\begin{array}{l}-8.6 * \\
(4.4)\end{array}$ & $\begin{array}{c}1.3 \\
(4.4)\end{array}$ & $\begin{array}{l}-1.4 \\
(5.7)\end{array}$ & $\begin{array}{c}6.3 \\
(4.6)\end{array}$ & $\begin{array}{l}-9.8 \\
(7.4)\end{array}$ & $\begin{array}{c}-17.9 * \\
(9.3)\end{array}$ & $\begin{array}{c}14.2 \\
(14.4)\end{array}$ & $\begin{array}{c}-16.1 * \\
(8.2)\end{array}$ & $\begin{array}{c}4.2 \\
(14.2)\end{array}$ \\
\hline Year 2004 & $\begin{array}{l}-1.8 \\
(4.8)\end{array}$ & & $\begin{array}{c}2.5 \\
(5.4)\end{array}$ & $\begin{array}{l}-1.1 \\
(5.9)\end{array}$ & $\begin{array}{l}-2.8 \\
(8.1)\end{array}$ & $\begin{array}{l}-3.9 \\
(7.5)\end{array}$ & $\begin{array}{l}-11.7 \\
(10.1)\end{array}$ & $\begin{array}{r}-11.0 \\
(8.3)\end{array}$ & $\begin{array}{l}-10.4 \\
(13.3)\end{array}$ & $\begin{array}{c}-1.1 \\
(15.8)\end{array}$ & $\begin{array}{c}32.8 \\
(25.5)\end{array}$ & $\begin{array}{c}3.3 \\
(14.4)\end{array}$ & $\begin{array}{c}-1.1 \\
(24.9)\end{array}$ \\
\hline Variance and covarianc & terms: & & & & & & & & & & & & \\
\hline $\begin{array}{l}\text { Transitory Error } \\
\text { Variance }\end{array}$ & $\begin{array}{r}117.2 \\
(1.5)\end{array}$ & $* * *$ & $\begin{array}{c}130.4 \\
(1.7)\end{array}$ & $\begin{array}{c}113.2 \\
(1.8)\end{array}$ & $\begin{array}{c}153.6 * * * \\
(2.8)\end{array}$ & $\begin{array}{c}183.4^{* * *} \\
(3.0)\end{array}$ & $\begin{array}{c}234.4 \\
(4.6)\end{array}$ & $\begin{array}{c}166.7 \text { *** } \\
(2.9)\end{array}$ & $\begin{array}{c}275.4 \\
(6.2)\end{array}$ & $\begin{array}{c}377.5 * * * \\
(9.8)\end{array}$ & $\begin{array}{l}492.3 * * * \\
(21.3)\end{array}$ & $\begin{array}{c}287.9 \\
(5.9)\end{array}$ & $\begin{array}{l}472.5 \text { *** } \\
(15.9)\end{array}$ \\
\hline $\begin{array}{l}\text { Transitory Error } \\
\text { Correlations }\end{array}$ & $\begin{array}{l}\rho_{P S, f, 1} \\
-0.038 \\
(0.022)\end{array}$ & $*$ & $\begin{array}{l}\rho_{P S, f, 2} \\
-0.191 \\
(0.024)\end{array}$ *** & $\begin{array}{c}\rho_{P S, m, 1} \\
0.092 \\
(0.026)\end{array}$ *** & $\begin{array}{l}\rho_{P S, m, 2} \\
-0.026 \\
(0.031)\end{array}$ & $\begin{array}{l}\rho_{P M, f, 1} \\
-0.376 * * * \\
(0.019)\end{array}$ & $\begin{array}{l}\rho_{P M, f, 2} \\
-0.116 * * * \\
(0.030)\end{array}$ & $\begin{array}{l}\rho_{P M, m, 1} \\
-0.382 \\
(0.022)\end{array} * * *$ & $\begin{array}{l}\rho_{P M, m, 2} \\
-0.220 * * * \\
(0.033)\end{array}$ & $\begin{array}{l}\rho_{S M, f, 1} \\
-0.592 * * * \\
(0.016)\end{array}$ & $\begin{array}{l}\rho_{S M, f, 2} \\
-0.476 * * * \\
(0.024)\end{array}$ & $\begin{array}{l}\rho_{S M, m, 1} \\
-0.569 * * * \\
(0.018)\end{array}$ & $\begin{array}{l}\rho_{S M, m, 2} \\
-0.484 * * * \\
(0.027)\end{array}$ \\
\hline $\begin{array}{l}\text { Discretely Distributed } \\
\text { Unobserved Factor } \\
\mu\end{array}$ & & & $\begin{array}{l}\text { Point } 1 \\
-1.000\end{array}$ & & $\begin{array}{c}\text { Point } 2 \\
1.252 \\
(0.089)\end{array}$ & & $\begin{array}{c}\text { Point } 3 \\
3.076 \\
(0.259)\end{array}$ & & $\begin{array}{l}\text { Weight } 1 \\
-0.489 \\
(0.017)\end{array}$ & & $\begin{array}{l}\text { Weight } 2 \\
2.741 \\
(0.126)\end{array}$ & & \\
\hline
\end{tabular}


Table B2

Family Structure Equations

\begin{tabular}{|c|c|c|c|c|c|c|}
\hline & Cohabiting & Married & Children 0-3 & Children 4-6 & Children 7-11 & Children 12-17 \\
\hline Intercept & $\begin{array}{l}-3.5466^{* * *} \\
(0.596)\end{array}$ & $\begin{array}{l}-7.869 * * * \\
(0.366)\end{array}$ & $\begin{array}{l}-4.070 * * * \\
(0.264)\end{array}$ & $\begin{array}{l}-6.176 \text { *** } \\
(0.262)\end{array}$ & $\begin{array}{l}-9.289 * * * \\
(0.256)\end{array}$ & $\begin{array}{c}-12.1677^{* * *} \\
(0.238)\end{array}$ \\
\hline Female & $\begin{array}{l}-0.165 * * \\
(0.083)\end{array}$ & $\begin{array}{l}-0.524 * * * \\
(0.047)\end{array}$ & $\begin{array}{l}-0.170 * * * \\
(0.029)\end{array}$ & $\begin{array}{l}-0.082 * * * \\
(0.026)\end{array}$ & $\begin{array}{l}0.058 * * \\
(0.023)\end{array}$ & $\begin{array}{l}0.123 \text { *** } \\
(0.022)\end{array}$ \\
\hline Age & $\begin{array}{l}0.148 \text { *** } \\
(0.028)\end{array}$ & $\begin{array}{l}0.399 * * * \\
(0.016)\end{array}$ & $\begin{array}{l}0.217 \text { *** } \\
(0.013)\end{array}$ & $\begin{array}{l}0.299 * * * \\
(0.012)\end{array}$ & $\begin{array}{l}0.463 * * * \\
(0.012)\end{array}$ & $\begin{array}{l}0.5466^{* * *} \\
(0.011)\end{array}$ \\
\hline Age Squared & $\begin{array}{l}-0.238 * * * \\
(0.037)\end{array}$ & $\begin{array}{l}-0.462 * * * \\
(0.019)\end{array}$ & $\begin{array}{l}-0.412 * * * \\
(0.018)\end{array}$ & $\begin{array}{l}-0.453 * * * \\
(0.016)\end{array}$ & $\begin{array}{l}-0.605 * * * \\
(0.014)\end{array}$ & $\begin{array}{l}-0.631 * * * \\
(0.013)\end{array}$ \\
\hline Black & $\begin{array}{l}-0.728 \text { *** } \\
(0.128)\end{array}$ & $\begin{array}{l}-1.851 \text { *** } \\
(0.066)\end{array}$ & $\begin{array}{l}-0.199 * * * \\
(0.047)\end{array}$ & $\begin{array}{l}-0.126 * * * \\
(0.044)\end{array}$ & $\begin{array}{c}0.009 \\
(0.037)\end{array}$ & $\begin{array}{l}-0.056 \\
(0.034)\end{array}$ \\
\hline Hispanic & $\begin{array}{l}-0.315 \text { ** } \\
(0.141)\end{array}$ & $\begin{array}{c}0.047 \\
(0.073)\end{array}$ & $\begin{array}{l}0.100 * * \\
(0.046)\end{array}$ & $\begin{array}{l}0.141 * * * \\
(0.044)\end{array}$ & $\begin{array}{l}0.096 * * \\
(0.040)\end{array}$ & $\begin{array}{l}0.094 * * \\
(0.039)\end{array}$ \\
\hline High School & $\begin{array}{c}0.165 \\
(0.131)\end{array}$ & $\begin{array}{l}0.259 \text { *** } \\
(0.078)\end{array}$ & $\begin{array}{c}0.032 \\
(0.049)\end{array}$ & $\begin{array}{l}-0.174 * * * \\
(0.049)\end{array}$ & $\begin{array}{l}-0.171 * * * \\
(0.043)\end{array}$ & $\begin{array}{l}-0.166 * * * \\
(0.040)\end{array}$ \\
\hline College & $\begin{array}{l}-0.390 * * \\
(0.159)\end{array}$ & $\begin{array}{l}0.7066^{* * *} \\
(0.085)\end{array}$ & $\begin{array}{l}0.376 \text { *** } \\
(0.054)\end{array}$ & $\begin{array}{c}0.001 \\
(0.052)\end{array}$ & $\begin{array}{l}-0.231 * * * \\
(0.046)\end{array}$ & $\begin{array}{l}-0.320 * * * \\
(0.043)\end{array}$ \\
\hline Midwest & $\begin{array}{l}-0.119 \\
(0.120)\end{array}$ & $\begin{array}{l}0.149 * * \\
(0.065)\end{array}$ & $\begin{array}{l}-0.021 \\
(0.041)\end{array}$ & $\begin{array}{c}0.050 \\
(0.038)\end{array}$ & $\begin{array}{l}-0.008 \\
(0.033)\end{array}$ & $\begin{array}{l}0.062 * \\
(0.032)\end{array}$ \\
\hline South & $\begin{array}{l}-0.265 * * \\
(0.116)\end{array}$ & $\begin{array}{l}0.168 \text { *** } \\
(0.061)\end{array}$ & $\begin{array}{l}-0.116 * * * \\
(0.039)\end{array}$ & $\begin{array}{l}-0.015 \\
(0.037)\end{array}$ & $\begin{array}{l}-0.046 \\
(0.031)\end{array}$ & $\begin{array}{c}0.037 \\
(0.030)\end{array}$ \\
\hline West & $\begin{array}{c}0.001 \\
(0.127)\end{array}$ & $\begin{array}{c}0.068 \\
(0.069)\end{array}$ & $\begin{array}{l}-0.027 \\
(0.043)\end{array}$ & $\begin{array}{c}0.038 \\
(0.041)\end{array}$ & $\begin{array}{l}-0.046 \\
(0.036)\end{array}$ & $\begin{array}{c}0.015 \\
(0.034)\end{array}$ \\
\hline Rural & $\begin{array}{l}0.300 \\
(0.099)\end{array}$ & $\begin{array}{l}0.221 * * * \\
(0.054)\end{array}$ & $\begin{array}{l}-0.055 \\
(0.035)\end{array}$ & $\begin{array}{c}0.017 \\
(0.033)\end{array}$ & $\begin{array}{l}0.096 \text { *** } \\
(0.028)\end{array}$ & $\begin{array}{l}0.109 * * * \\
(0.026)\end{array}$ \\
\hline Unemployment Rate & $\begin{array}{l}-0.078 * \\
(0.046)\end{array}$ & $\begin{array}{l}-0.040 \\
(0.025)\end{array}$ & $\begin{array}{c}0.017 \\
(0.016)\end{array}$ & $\begin{array}{c}0.023 \\
(0.015)\end{array}$ & $\begin{array}{l}-0.013 \\
(0.013)\end{array}$ & $\begin{array}{c}0.013 \\
(0.012)\end{array}$ \\
\hline Year 2004 & $\begin{array}{l}0.207 \text { ** } \\
(0.085)\end{array}$ & $\begin{array}{c}0.062 \\
(0.044)\end{array}$ & $\begin{array}{c}0.014 \\
(0.028)\end{array}$ & $\begin{array}{c}0.041 \\
(0.026)\end{array}$ & $\begin{array}{c}0.003 \\
(0.023)\end{array}$ & $\begin{array}{c}0.006 \\
(0.022)\end{array}$ \\
\hline$\tau_{1}$ & & & $\begin{array}{l}1.181 * * * \\
(0.020)\end{array}$ & $\begin{array}{l}1.297 * * * \\
(0.023)\end{array}$ & $\begin{array}{l}1.016 \text { *** } \\
(0.015)\end{array}$ & $\begin{array}{l}0.900 * * * \\
(0.015)\end{array}$ \\
\hline$\tau_{2}$ & & & & & $\begin{array}{l}2.123 * * * \\
(0.036)\end{array}$ & $\begin{array}{l}1.932 \text { *** } \\
(0.034)\end{array}$ \\
\hline$\lambda$ & $\begin{array}{l}0.300 * * * \\
(0.058)\end{array}$ & $\begin{array}{l}1.273 \text { *** } \\
(0.063)\end{array}$ & 1.000 & $\begin{array}{l}0.748 \text { *** } \\
(0.040)\end{array}$ & $\begin{array}{l}0.579 * * * \\
(0.028)\end{array}$ & $\begin{array}{l}0.198 \text { *** } \\
(0.017)\end{array}$ \\
\hline
\end{tabular}

Log Likelihood $\quad-118005.91$

Notes: Table reports selected coefficients and asymptotic standard errors (in parentheses) from correlated Tobit models of time use and discrete-choice models of family structure estimated using data from the ATUS. Estimates for the remaining time use coefficients are reported in Table 2.

* Significant at .10 level. ** Significant at .05 level. *** Significant at .01 level. 
Appendix C. Remaining Coefficient Estimates from Correlated Tobit Models of Time-Use: UKTUS Sample

Table C1

Time Use Equations

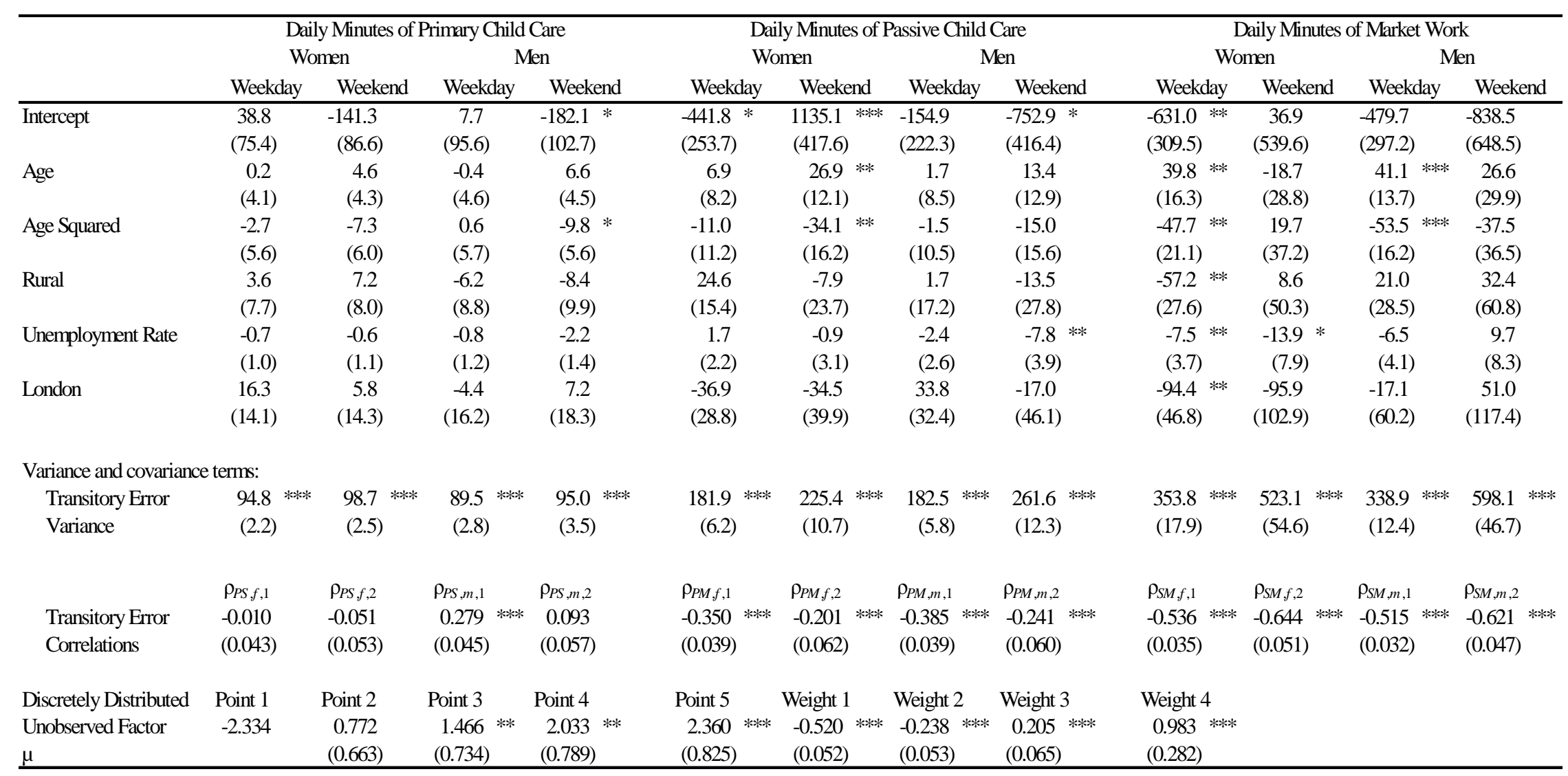


Table C2

Family Structure Equations

\begin{tabular}{|c|c|c|c|c|c|c|}
\hline & Cohabiting & Married & Children 0-3 & Children 4-6 & Children 7-11 & Children 12-17 \\
\hline Intercept & $\begin{array}{l}-6.481 * * * \\
(0.846)\end{array}$ & $\begin{array}{l}-10.739 \text { **** } \\
(0.728)\end{array}$ & $\begin{array}{l}-6.833 * * * \\
(0.955)\end{array}$ & $\begin{array}{l}-9.680^{* * *} \\
(0.922)\end{array}$ & $\begin{array}{l}-13.1677^{* * *} \\
(0.767)\end{array}$ & $\begin{array}{l}-13.9477^{* * *} \\
(0.654)\end{array}$ \\
\hline Female & $\begin{array}{l}-0.305 * * \\
(0.126)\end{array}$ & $\begin{array}{l}-0.230 * * \\
-0.101\end{array}$ & $\begin{array}{l}-0.019 \\
(0.083)\end{array}$ & $\begin{array}{c}0.050 \\
(0.078)\end{array}$ & $\begin{array}{l}0.148 * * \\
(0.072)\end{array}$ & $\begin{array}{l}0.150 \text { *** } \\
(0.057)\end{array}$ \\
\hline Age & $\begin{array}{l}0.294 * * * \\
(0.044)\end{array}$ & $\begin{array}{r}0.500 \\
-0.032\end{array}$ & $\begin{array}{l}0.3244^{* * *} \\
(0.031)\end{array}$ & $\begin{array}{l}0.457 * * * \\
(0.041)\end{array}$ & $\begin{array}{l}0.631 \\
(0.034)\end{array}$ & $\begin{array}{l}0.626 \\
(0.030)\end{array}$ \\
\hline Age Squared & $\begin{array}{l}-0.3900^{* * *} \\
(0.057)\end{array}$ & $\begin{array}{l}-0.513 * * * \\
(0.039)\end{array}$ & $\begin{array}{l}-0.5433^{* * *} \\
(0.046)\end{array}$ & $\begin{array}{l}-0.6699^{* * *} \\
(0.057)\end{array}$ & $\begin{array}{l}-0.8155^{* * *} \\
(0.043)\end{array}$ & $\begin{array}{l}-0.7177^{* * *} \\
(0.034)\end{array}$ \\
\hline $\begin{array}{l}\text { First or Post-Grad } \\
\text { Degree }\end{array}$ & $\begin{array}{l}0.4677^{* *} \\
(0.194)\end{array}$ & $\begin{array}{l}-0.150 \\
-0.159\end{array}$ & $\begin{array}{l}-0.397 * * * \\
(0.132)\end{array}$ & $\begin{array}{l}-0.468 \text { *** } \\
(0.132)\end{array}$ & $\begin{array}{l}-0.418{ }^{* * *} \\
(0.112)\end{array}$ & $\begin{array}{l}-0.158 * \\
(0.094)\end{array}$ \\
\hline $\begin{array}{l}\text { Other Higher Educ. } \\
\text { Degree }\end{array}$ & $\begin{array}{l}-0.295 \\
(0.367)\end{array}$ & $\begin{array}{r}0.156 \\
-0.276\end{array}$ & $\begin{array}{l}-0.485 * * \\
(0.228)\end{array}$ & $\begin{array}{l}-0.479 * * \\
(0.241)\end{array}$ & $\begin{array}{l}-0.441 * * \\
(0.197)\end{array}$ & $\begin{array}{l}-0.427^{* *} \\
(0.187)\end{array}$ \\
\hline $\begin{array}{l}\text { Higher Educ. Below } \\
\text { Degree Level }\end{array}$ & $\begin{array}{c}0.243 \\
(0.213)\end{array}$ & $\begin{array}{l}-0.126 \\
(0.152)\end{array}$ & $\begin{array}{l}-0.267 * * \\
(0.135)\end{array}$ & $\begin{array}{l}-0.338 \text { *** } \\
(0.129)\end{array}$ & $\begin{array}{l}-0.205 * \\
(0.111)\end{array}$ & $\begin{array}{l}-0.115 \\
(0.089)\end{array}$ \\
\hline "A" level or voc. level 3 & $\begin{array}{l}0.422 \\
(0.204)\end{array}$ & $\begin{array}{r}0.254 \\
-0.156\end{array}$ & $\begin{array}{l}-0.3622^{* * *} \\
(0.120)\end{array}$ & $\begin{array}{l}-0.227 * \\
(0.124)\end{array}$ & $\begin{array}{l}-0.145 \\
(0.102)\end{array}$ & $\begin{array}{l}-0.222 * * \\
(0.103)\end{array}$ \\
\hline "O" level, gcse grade a-c & $\begin{array}{c}0.161 \\
(0.187)\end{array}$ & $\begin{array}{r}0.108 \\
-0.132\end{array}$ & $\begin{array}{l}-0.163 \\
(0.104)\end{array}$ & $\begin{array}{l}-0.200 * \\
(0.106)\end{array}$ & $\begin{array}{l}-0.123 \\
(0.087)\end{array}$ & $\begin{array}{l}-0.071 \\
(0.078)\end{array}$ \\
\hline gcse below grade c & $\begin{array}{l}-0.493 \\
(0.398)\end{array}$ & $\begin{array}{l}-0.053 \\
(0.239)\end{array}$ & $\begin{array}{l}-0.102 \\
(0.169)\end{array}$ & $\begin{array}{c}0.002 \\
(0.184)\end{array}$ & $\begin{array}{l}-0.021 \\
(0.164)\end{array}$ & $\begin{array}{l}-0.019 \\
(0.146)\end{array}$ \\
\hline $\begin{array}{l}\text { Other Known } \\
\text { Qualifications }\end{array}$ & $\begin{array}{l}-0.006 \\
(0.295)\end{array}$ & $\begin{array}{l}-0.073 \\
-0.198\end{array}$ & $\begin{array}{l}-0.244 \\
(0.159)\end{array}$ & $\begin{array}{c}0.084 \\
(0.157)\end{array}$ & $\begin{array}{l}-0.030 \\
(0.150)\end{array}$ & $\begin{array}{l}-0.045 \\
(0.115)\end{array}$ \\
\hline Rural & $\begin{array}{l}-0.023 \\
(0.133)\end{array}$ & $\begin{array}{l}0.263 \\
-0.099\end{array}$ & $\begin{array}{l}-0.006 \\
(0.082)\end{array}$ & $\begin{array}{c}0.134 \\
(0.081)\end{array}$ * & $\begin{array}{c}0.046 \\
(0.070)\end{array}$ & $\begin{array}{l}-0.108 \text { * } \\
(0.058)\end{array}$ \\
\hline Unemployment Rate & $\begin{array}{l}-0.015 \\
(0.017)\end{array}$ & $\begin{array}{l}-0.075 \\
(0.013)\end{array}$ & $\begin{array}{l}-0.003 \\
(0.010)\end{array}$ & $\begin{array}{l}-0.001 \\
(0.010)\end{array}$ & $\begin{array}{c}0.010 \\
(0.008)\end{array}$ & $\begin{array}{c}0.003 \\
(0.007)\end{array}$ \\
\hline London & $\begin{array}{l}-0.305 \\
(0.211)\end{array}$ & $\begin{array}{l}-0.310 \\
-0.170\end{array}$ & $\begin{array}{l}-0.203 \\
(0.137)\end{array}$ & $\begin{array}{c}0.072 \\
(0.141)\end{array}$ & $\begin{array}{c}0.113 \\
(0.111)\end{array}$ & $\begin{array}{l}-0.055 \\
(0.099)\end{array}$ \\
\hline$\tau_{1}$ & & & $\begin{array}{l}1.221 \text { *** } \\
(0.064)\end{array}$ & $\begin{array}{l}1.287 \text { *** } \\
(0.074)\end{array}$ & $\begin{array}{l}0.980 \text { *** } \\
(0.043)\end{array}$ & $\begin{array}{l}0.798 \text { *** } \\
(0.035)\end{array}$ \\
\hline$\tau_{2}$ & & & & & $\begin{array}{l}2.188 \text { *** } \\
(0.109)\end{array}$ & $\begin{array}{l}1.802 \text { *** } \\
(0.078)\end{array}$ \\
\hline$\lambda$ & $\begin{array}{l}0.3111^{* * * *} \\
(0.081)\end{array}$ & $\begin{array}{l}0.621{ }^{* * *} \\
(0.120)\end{array}$ & 1.000 & $\begin{array}{l}0.769 \text { *** } \\
(0.175)\end{array}$ & $\begin{array}{l}0.514 \\
(0.094)\end{array}$ & $\begin{array}{l}0.129 * * * \\
(0.033)\end{array}$ \\
\hline Log Likelihood & -35713.67 & & & & & \\
\hline
\end{tabular}




\section{Endnotes}

${ }^{1}$ Folbre, Yoon, Finnoff, and Fuligni (2005) argue for an even more inclusive measure that includes time spent while the child is sleeping. Bianchi (2000) and Kalenkoski, Ribar, and Stratton (2005) look at time spent on secondary child care.

${ }^{2}$ An advantage of The UKTUS over the ATUS is that all intrahousehold relationships are identified. Thus, it is possible to 'fix' misreported relations using other information in the sample and to accurately identify all children of cohabiting partners. In this respect, the UKTUS sample will be 'cleaner' than the ATUS sample. However, a comparison of the UKTUS sample used here with another constructed using the same restrictions imposed upon the ATUS reveals only minor differences. Most notably, less than 40 households with unrelated children and only 1 adult (who might reasonably be considered the legal guardian) are excluded from our UKTUS sample but would be included under ATUS sample rules.

${ }^{3}$ Diaries containing fewer than five different activity codes and those missing more than one hour of information are excluded from both the ATUS and the UKTUS diary samples.

${ }^{4}$ According to comparable statistics for dependent children published by the Office of National Statistics in the U.K. (http://www.statistics.gov.uk/cci/nugget.asp?id=1163) for 2004, 67\% of the women were married, $11 \%$ were cohabiting, and $22 \%$ were single. The corresponding figures for men were $84 \%, 14 \%$, and $2.5 \%$ respectively.

${ }^{5}$ National statistics for the United States come from the Bureau of the Census, http://www.census.gov/prod/2004pubs/censr-14.pdf , Table 3.

6 Estimation actually proceeded using ordered probit models with known thresholds (60 minute intervals) as aML was unable to estimate the logit specification with family structure equations using a discretely distributed unobserved factor. The maximum allowable time threshold was 11 hours except in the case of primary childcare on weekends/holidays in the U.K. where the maximum was 6 hours.

${ }^{7}$ The aML software uses a normal distribution to transform the probabilities. Let $\Phi(\cdot)$ represent the standard normal distribution. With the transformation, the probability of the first point would be $\Phi\left(\omega_{1}\right)$; the probability of the second point would be $\Phi\left(\omega_{2}\right)-\Phi\left(\omega_{1}\right)$, and the probability of the last point would be $1-\Phi\left(\omega_{2}\right)$. 